I998: I

\title{
Toxicokinetics of Inhaled Trimethylbenzenes in Man
}

fill Färnberg

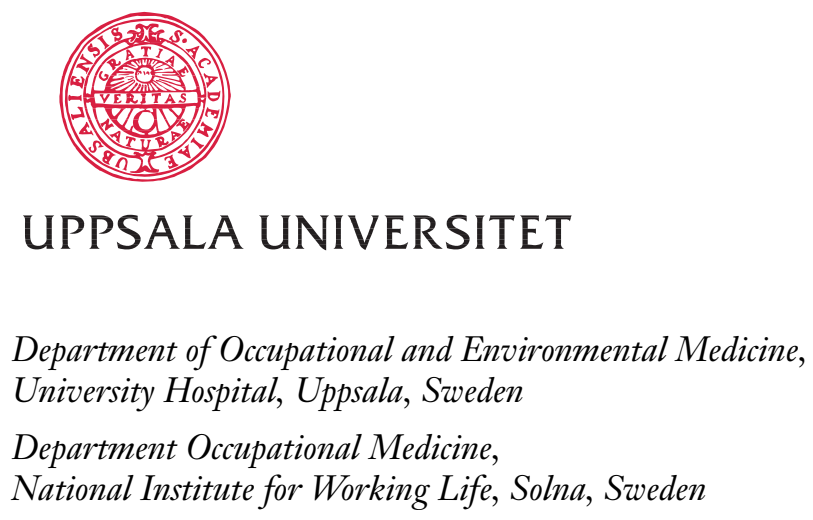

ARBETE OCH HÄLSA VETENSKAPLIG SKRIFTSERIE

ISBN 9 I-7045-457-4 ISSN 0346-782 I http://www.niwl.se/ah/ah.htm

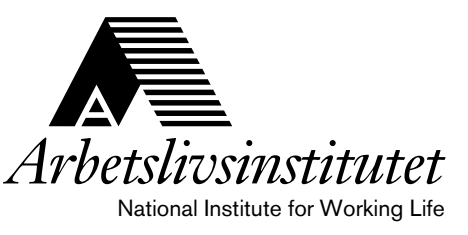




\section{National Institute for Working Life}

The National Institute for Working Life is Sweden's center for research and development on labour market, working life and work environment. Diffusion of information, training and teaching, local development and international collaboration are other important issues for the Institute.

The R\&D competence will be found in the following areas: Labour market and labour legislation, work organization and production technology, psychosocial working conditions, occupational medicine, allergy, effects on the nervous system, ergonomics, work environment technology and musculoskeletal disorders, chemical hazards and toxicology.

A total of about 470 people work at the Institute, around 370 with research and development. The Institute's staff includes 32 professors and in total 122 persons with a postdoctoral degree.

The National Institute for Working Life has a large international collaboration in $\mathrm{R} \& \mathrm{D}$, including a number of projects within the EC Framework Programme for Research and Technology Development.

ARBETE OCH HÄLSA

Redaktör: Anders Kjellberg

Redaktionskommitté: Anders Colmsjö

och Ewa Wigaeus Hjelm

(C) Arbetslivsinstitutet \& författarna 1998

Arbetslivsinstitutet,

17184 Solna, Sverige

ISBN 91-7045-457-4

ISSN 0346-7821

http://www.niwl.se/ah/ah.htm

Tryckt hos CM Gruppen 
Till Linn och Lovisa 


\section{List of publications}

This thesis is based on the publications listed below, referred to in the text by their Roman numerals. The papers are reproduced with the kind permission of the publisher of the respective journal.

I Järnberg J, Johanson G. Liquid/air partition coefficients of the trimethylbenzenes. Toxicol Ind Health 1995;11(1):81-88.

II Järnberg J, Johanson G, Löf A. Toxicokinetics of inhaled trimethylbenzenes in man. Toxicol Appl Pharmacol 1996;140:281-288.

III Ståhlbom B, Järnberg J, Söderkvist P, Lindmark D. Determination of dimethylhippuric acid isomers in urine by high-performance liquid chromatography. Int Arch Occup Environ Health 1996;69:147-150.

IV Järnberg J, Johanson G, Löf A, Ståhlbom B. Urinary excretion of dimethylhippuric acids in humans after exposure to trimethylbenzenes. Int Arch Occup Environ Health 1997;69:491-497.

V Järnberg J, Johanson G, Löf A, Ståhlbom B. Toxicokinetics of 1,2,4trimethylbenzene in humans exposed to vapours of white spirit comparison with exposure to 1,2,4-trimethylbenzene alone (submitted). 1998.

VI Järnberg, J. Johanson, G. Physiologically based modelling of 1,2,4trimethylbenzene inhalation toxicokinetics (manuscript). 


\section{Abbreviations}

ACGIH American Conference of Governmental Industrial Hygienists

ANOVA analysis of variance

CNS central nervous system

DMBA dimethylbenzoic acid

DMHA dimethylhippuric acid

HPLC high performance liquid chromatography

IRLS iteratively reweighted least squares

$\lambda \quad$ partition coefficient

OEL occupational exposure limit

OLS ordinary least squares

PBTK physiologically based toxicokinetic

ppm parts per million $\left(\mathrm{ml} / \mathrm{m}^{3}\right)$

TLV threshold limit value

TMB trimethylbenzene

TWA time-weighted average 


\title{
Table of contents
}

\author{
List of original papers
}

Abbreviations

1. Introduction 1

1.1 Toxicokinetics and biological monitoring 1

1.2 Aims of the study 3

2. Review of the literature on the trimethylbenzenes 4

2.1 Chemical structure and nomenclature 4

2.2 Physical properties 4

2.3 Occurrence $\quad 5$

2.4 Toxicokinetics $\quad 6$

2.5 Toxicity $\quad 8$

2.6 Occupational exposure and biological monitoring $\quad 10$

$\begin{array}{ll}2.7 \text { Occupational exposure limits } & 11\end{array}$

3. Methods 12

3.1 Determination of liquid/air partition coefficients in vitro 12

$\begin{array}{ll}3.2 \text { Chamber exposures } & 12\end{array}$

$\begin{array}{ll}3.3 \text { Toxicokinetic calculations } & 14\end{array}$

3.4 Chemical analysis of metabolites in urine $\quad 16$

$\begin{array}{ll}3.5 \text { Rating of acute symptoms } & 16\end{array}$

3.6 Physiologically based modelling of 1,2,4-TMB inhalation kinetics 16

$\begin{array}{ll}3.7 \text { Statistical analysis } & 19\end{array}$

4. Results 20

4.1 Liquid/air partition coefficients 20

4.2 Inhalation toxicokinetics of the TMBs 20

4.3 Physiologically based modelling of 1,2,4-TMB inhalation kinetics 25

$\begin{array}{ll}4.4 \text { Acute symptoms } & 27\end{array}$

5. Discussion 28

5.1 Toxicokinetic data analysis 28

5.2 Inhalation toxicokinetics of the TMBs 29

5.3 Physiologically based modelling of 1,2,4-TMB inhalation kinetics 33

$\begin{array}{ll}5.4 \text { Biological monitoring of TMB exposure } & 35\end{array}$

$\begin{array}{ll}5.5 \text { Acute symptoms } & 37\end{array}$

$\begin{array}{ll}\text { 6. Conclusions } & 39\end{array}$ 
7. Summary 40

8. Sammanfattning (Summary in Swedish) 41

9. Acknowledgements 42

10. References 44

APPENDIX: PAPERS I-VI 


\section{Introduction}

The trimethylbenzenes (TMBs) occur naturally in crude and shale oil. Due to their presence in petroleum high volume chemicals such as motor fuels and solvent mixtures the trimethylbenzenes are widely spread. Their exposure potential is therefore high and they occur in ambient air and in occupational settings and may pose a problem to human health and/or to the environment. The molecular formula of the TMBs is the same for several other substances (e.g. methyl ethylbenzene, propylbenzene, cumene) collectively referred to as $\mathrm{C}_{9}$ aromatics. The TMBs also belong to the alkylbenzenes, such as toluene, ethylbenzene and the xylenes. Due to the relatively high volatility of substances like the TMBs, the main route of exposure is via inhalation. In general, the alkylbenzenes are known to be narcotics and irritants to skin and mucous membranes (5).

Environmental concern has also been given the alkylbenzenes due to their photochemical reactivity. The TMBs thereby contribute substantially to the increase of photochemical oxidants, mainly ground-level ozone.

Data on the uptake and disposition of a chemical is important in the process of risk assessment. Although the TMBs are frequently in use, such quantitative human data was sparse when this work was initiated.

An exposure chamber for humans is at our disposal in our laboratory. It is thereby possible to perform well defined and controlled experimental inhalation exposures, a prerequisite for quantitative studies on uptake and disposition. The chamber is $20 \mathrm{~m}^{3}$ and the subjects may be exposed at rest or exercise. Exposure levels used in our studies do not exceed the present occupational exposure limits.

\subsection{Toxicokinetics and biological monitoring}

The toxicity of a chemical can be described by its kinetic and dynamic characteristics. Toxicokinetics is the mathematical description of the time course of a chemical in the body. It comprises of different processes: the uptake, distribution, metabolism (biotransformation) and excretion. Thus, toxicokinetics provides information on the concentration of the chemical at the site of action. The underlying assumption is that a potential risk to health is related to that target tissue concentration or internal dose of the chemical or its metabolites. The toxicodynamic features describe the mechanism of action at the target site. Traditionally, in the occupational setting air levels have been used to estimate the internal dose. One advantage of ambient air monitoring is that it gives a measure of the occupational exposure alone. For a variety of reasons, however, ambient monitoring may not reflect the internal dose. In the case of varying exposure levels the sampling period may be too short. Further, an increased physical activity will increase pulmonary ventilation and cardiac output thereby affecting uptake, distribution and elimination. Individual characteristics, such as constitution or metabolic capacity will also affect target tissue dose and hence, the 
risk for adverse human health effects. Also, other routes of exposure, e.g. dermal uptake may contribute to the total internal dose.

Instead of using air levels, internal dose may be estimated from biological exposure indices, e.g. the concentration of the parent compound or its metabolites in blood, urine or exhaled air. Biological exposure indices will reflect all, not only occupational, exposure. Biological sampling is also the only possible way of evaluating the performance of personal protective equipment.

Most experimental studies on kinetics or toxicity are performed on single chemicals, while occupational and environmental exposures often are to mixtures of substances. Toxicokinetic (and toxicodynamic) interactions between chemicals or components in mixtures may occur which in turn affect risk assessment. Further, the proper use of biological exposure indices from multiple exposure situations requires an awareness of such interactions.

Toxicokinetic modelling may be used to describe, predict or explain data and is largely based on the visualisation of the body as consisting of one or several compartments. Two commonly used types of toxicokinetic modelling are a) data based and b) physiologically based. The classical descriptive, data based compartmental analysis is based on mathematical regression and curve fitting. The number and characteristics of the compartments depend on the equation chosen to describe the data. By the second approach, physiologically based pharmaco- or toxicokinetic modelling, the organism is described by physiologically realistic compartments (tissue groups) of known volumes with connecting blood flows. Tissues are lumped together into compartments according to blood flow and fat content. Apart from physiological characteristics such as organ volumes and blood flows, also chemical specific data such as partition coefficients and reaction rate constants are included. Partition coefficients determine how a substance will divide between different media, e.g. blood and air, and are decisive for the toxicokinetic behaviour of the chemical. Mathematically, the physiological model is defined by a set of mass balance equations or differentials. Such models have a higher predictive power than the data based mathematical models and allow for extrapolating, e.g. between dose levels and species. Thus, the influence on the kinetics from co-exposure to other xenobiotics, physical exercise and individual characteristics may be studied making physiological modelling a valuable tool in risk assessment and in the development of biological markers. 


\subsection{Aims of the study}

The main purpose of this thesis was to study the toxicokinetics of the trimethylbenzenes in humans and to obtain quantitative data in order to address the issue of biological monitoring of exposure to TMB-containing products. More specifically the aims were to:

a. study the inhalation toxicokinetics, i.e. respiratory uptake, distribution, metabolism and excretion of 1,2,3-, 1,2,4- and 1,3,5-TMB, respectively (Paper II).

b. compare the inhalation toxicokientics of the TMBs, and 1,2,4-TMB in particular, after exposure to the substances alone with the kinetics after exposure to a commonly used TMB-containing product, i.e. white spirit (Paper V).

c. study the urinary excretion of specific metabolites and their suitability as biological markers of exposure (Papers III and IV).

d. develop a physiologically based toxicokinetic model for inhalation exposure of 1,2,4-TMB to expand to different exposure scenarios and address the issue of biological exposure monitoring (Papers I and VI).

e. screen for acute symptoms of irritation and CNS-effects (Papers II and V). 


\section{Review of the literature on the trimethylbenzenes}

\subsection{Chemical structure and nomenclature}

TMBs are mono-aromatic hydrocarbons with the molecular formula $\mathrm{C}_{9} \mathrm{H}_{12}$. Like the xylenes the methyl groups can be positioned in different ways giving three isomeric forms of TMBs. These are 1,2,3-TMB, 1,2,4-TMB and 1,3,5-TMB (Figure 1). Common names and CAS-numbers are given in Table 1.<smiles>Cc1cccc(C)c1C</smiles>

$1,2,3-\mathrm{TMB}$<smiles>Cc1ccc(C)c(C)c1</smiles>

$1,2,4-\mathrm{TMB}$<smiles>Cc1cc(C)cc(C)c1</smiles>

$1,3,5-\mathrm{TMB}$

Figure 1. Structural formulas of the TMBs.

\subsection{Physical properties}

The TMBs are clear, colourless liquids with aromatic oily odours which for the 1,3,5-isomer has been described as sweet or peculiar. An odour threshold of 0.55 ppm is reported for that isomer. The TMBs are miscible with organic solvents such as benzene, ethanol, and ethyl ether but are practically insoluble in water. The molecular weight is 120.2 . For conversion between $\mathrm{mg} / \mathrm{m}^{3}$ and $\mathrm{ppm}\left(\mathrm{ml} / \mathrm{m}^{3}\right)$,

Table 1. Nomenclature of the TMBs

\begin{tabular}{lrl}
\hline Rational name & CAS-No. & Synonyms \\
\hline $1,2,3-\mathrm{TMB}$ & $526-73-8$ & Hemimellitene \\
$1,2,4-\mathrm{TMB}$ & $95-63-6$ & $\begin{array}{l}\text { Pseudocumene, asymmetrical TMB, } \\
\text { pseudocumol, psi-cumene }\end{array}$ \\
$1,3,5-\mathrm{TMB}$ & $108-67-8$ & Mesitylene, symmetrical TMB \\
Mixed isomers & $25551-13-7$ & \\
\hline
\end{tabular}


Table 2. Physical properties of the TMBs

\begin{tabular}{llll}
\hline Property & $1,2,3-\mathrm{TMB}$ & $1,2,4-\mathrm{TMB}$ & $1,3,5-\mathrm{TMB}$ \\
\hline Boiling point $\left({ }^{\circ} \mathrm{C}\right)$ & 176 & 169 & 165 \\
Melting point $\left({ }^{\circ} \mathrm{C}\right)$ & -25.4 & -43.8 & -44.7 \\
Density $\left(\mathrm{g} / \mathrm{ml}, 20^{\circ} \mathrm{C}\right)$ & 0.8987 & 0.8761 & 0.8637 \\
Vapour pressure $(\mathrm{kPa})$ & $0.233\left(35^{\circ} \mathrm{C}\right)$ & $45.5(140 \mathrm{C})$ & $0.248\left(20^{\circ} \mathrm{C}\right)$ \\
Satur vapour conc $(\mathrm{ppm})$ & $1320\left(17^{\circ} \mathrm{C}\right)$ & $6500\left(38^{\circ} \mathrm{C}\right)$ & $6550\left(35^{\circ} \mathrm{C}\right)$ \\
Flash point $\left({ }^{\circ} \mathrm{C}\right)$ & 51 & 44 & 50
\end{tabular}

$1 \mathrm{mg} / \mathrm{m}^{3}=0.20 \mathrm{ppm}$ and $1 \mathrm{ppm}=4.92 \mathrm{mg} / \mathrm{m}^{3}$ at $25^{\circ} \mathrm{C}$. Some other physical properties are listed in Table $2(20,50-52,58)$. Estimated Log octanol-water partition coefficient $\left(\mathrm{K}_{\mathrm{ow}}\right)$ for the TMBs is 3.63 (62). The corresponding experimental value for $1,3,5-\mathrm{TMB}$ is 3.42 (33).

\subsection{Occurrence}

$1,3,5-\mathrm{TMB}$ is used as an intermediate in the dye and plastics industries and as a synthetic intermediate in the production of an antioxidant used as stabiliser in polymers like polyethylene, polypropylene, polyamides, adhesives, rubbers and wax and printing inks. 1,3,5-TMB is also used in paint and varnish formulations, in paint thinners, and in pesticide formulations (50).

Oxidation of 1,2,4-TMB yields trimellitic acid which may be converted to its anhydride. Trimellitic anhydride is used as an intermediate in the manufacture of alkyd resins, plasticizers and unsaturated polyesters, adhesives, dyes and printing inks (1). 1,2,4-TMB is also used as solvent for coatings, cleaning fluids, pesticide formulations and inks. It occurs in scintillation counting fluids, dye carriers and ultraviolet stabilisers in plastics and polymer resins (51). It is an insect attractant. The US production of 1,2,4-TMB was 36000 ton in 1989 (41). 1,2,3-TMB is used in the manufacturing of perfumes (52).

Finally, all TMB isomers occur in motor fuels and in solvent mixtures. The dominating isomer, 1,2,4-TMB, is registered in 145 products in Sweden covering solvent mixtures and a few scintillation counting fluids. The figure is an underestimation since the occurrence of TMBs in complex products may not be explicitly reported (75). Neat TMBs are not used at all, except for laboratory uses. The largest quantities are used in petrol (containing approximately 2\% TMBs) and 78D0 tons of TMBs were produced for that purpose in Sweden in 1992 (41). As a consequence of the occurrence in vehicle fuel, TMBs have been detected in urban air in trace quantities $(55,81-83)$. Main end uses of solvent mixtures are, e.g. in the surface coating, adhesives and the rubber industry. Common products containing TMBs are for instance with trade names: Shellsol, Solvesso and White 
Spirits. The fraction of TMBs in these products varies from a few percent up to approximately $50 \%$.

\subsection{Toxicokinetics}

Absorption occurs predominately and readily via inhalation, but also from the gastrointestinal tract (4). Limited data suggests that uptake through the skin is slow (31). The TMBs passes the placenta $(15,87)$. The in vitro blood/air partition coefficient of 1,3,5-TMB has been determined to be 44 (39) and that of 1,2,4TMB to be 54 and $87(13,86)$. The relative respiratory uptake in man exposed for $2 \mathrm{~h}$ at rest to $1,2,4-\mathrm{TMB}$ in white spirit has been estimated to be $62 \%$ (94). The uptake of 1,3,5-TMB during an 8-h inhalation at rest stabilised at $67 \%$ after $2 \mathrm{~h}$ (49).

No estimations of the human distribution of TMBs had been performed when this work was initiated. In rats exposed to $100 \mathrm{ppm}$ of 1,2,4-TMB, the by far highest concentrations were found in fat. Of organs measured, the kidney (91), or kidney and liver (36), had the highest levels. In humans exposed to 1,3,5-TMB vapour a triphasic elimination profile with a slow terminal phase was shown (49) indicating an affinity for adipose tissue.

Generally, alkylbenzenes are hydroxylated by the cytochrome P-450 system (57). It has not been shown what isozyme is responsible for the initial oxidation of the TMBs. The corresponding biotransformation of toluene and $m$-xylene, however is catalysed by the CYP2E1 isozyme $(59,67)$.

Oxidation can occur at the aromatic nucleus or at the aliphatic side chain. Initial aromatic hydroxylation yields a trimethylphenol. Side chain oxidation gives initially a dimethylbenzyl alcohol. The alcohols and phenols may be sulphated or glucuronidated. Conjugation with glutathione also occurs yielding finally a mercapturic acid derivative. Instead of being conjugated, dimethylbenzyl alcohol may be further oxidised to dimethylbenzoic acid (DMBA). The DMBAs in turn may be excreted directly in the urine or conjugate with glucuronic acid or glycine. The glycine conjugate is called dimethylhippuric acid (DMHA). Indications of DMHAs being further conjugated have been reported (36). The metabolic pathways of the TMBs are given in Figure 2 exemplified with 1,2,4-TMB. Due to the asymmetry of the $1,2,4-\mathrm{TMB}$ molecule the number of potential metabolites is large.

In the male rat, most of the above mentioned metabolites of 1,2,4-TMB have been detected after oral administration. The most predominant metabolites are conjugated dimethylbenzyl alcohols (26\% of administered dose) and DMHA (approximately 40\%) $(36,64)$. Some controversy exists about the importance of aromatic hydroxylation. Reported values range from $0.05 \%$ to $12 \%$ of equivalent oral doses $(4,36)$. Glucuronides and sulphates have been estimated to account for 7 and $13 \%$ respectively, of orally administered 1,2,4-TMB (64).

In the male Wistar rat, 3,5-DMHA is the main metabolite (42\% or 78\%) (63, 64 ) of 1,3,5-TMB while the urinary excretion of 2,4,6-trimethylphenol is very low $(0.4-0.5 \%)(4,63)$. Urinary metabolites also include a mercapturic acid derivative 

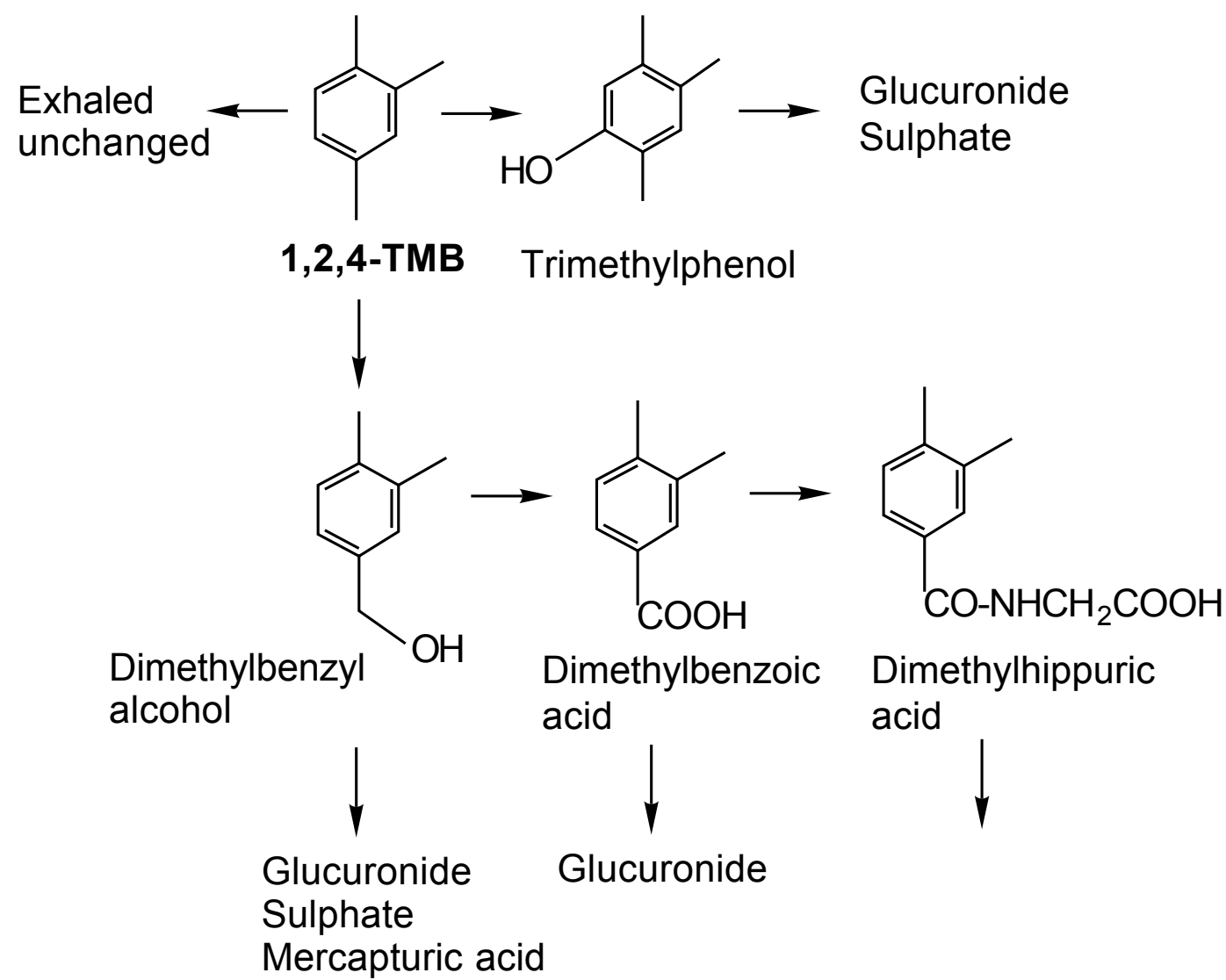

Figure 2. Suggested metabolism and elimination of the TMBs, exemplified by 1,2,4TMB.

(4\%) (88). In male rabbits, the urinary excretion of 3,5-DMHA (68.5\%), free 3,5DMBA (9\%) but also a diacid, 5-methylisophtalic acid (1.2\%) is reported (53). A tendency, although not significant, towards increased 1,3,5-TMB blood levels was seen in rats after intraperitoneal injection of ethanol $(20 \mathrm{mmole} / \mathrm{kg})$ before exposure to 110 and $580 \mathrm{ppm}$ of 1,3,5-TMB (76). Co-exposure with benzene has been found to increase the yield of DMHA from 42 to $59 \%$ (63).

In humans exposed to 1,3,5-TMB vapour the half-times of 1,3,5-TMB in blood were $1.6 \mathrm{~min}, 0.72 \mathrm{~h}$ and $46 \mathrm{~h}$, respectively. As much as $73 \%$ of the absorbed dose was recovered as 3,5-DMBA or 3,5-DMHA. Half-times of free and conjugated DMBAs were $6.5 \mathrm{~h}$ and $34.7 \mathrm{~h}$ (49). A urine/air partition coefficient of 18.5 for 1,3,5-TMB has been reported (39).

Published data on the kinetics of 1,2,3-TMB were very few when this work was initiated. In rats, glycine conjugates, glucuronides and sulphates were excreted in roughly equal proportions, each corresponding to $17-20 \%$ of an oral dose (1.2 $\mathrm{g} / \mathrm{kg}$ ) (64). Only $0.3 \%$ of an orally administered dose was excreted as urinary phenols (63). 
The influence from sterical factors might be seen in the metabolite pattern of the different TMB isomers. Oxidation at the aromatic nucleus seems relatively insensitive to sterical factors considering that the three possible phenols arising from oxidation of 1,2,4-TMB are formed at approximately equal proportions. Some sterical influence on initial side chain oxidation seems to occur but even more so on the successive oxidation of the dimethylbenzyl alcohols. Thus, the 3,4-dimethylbenzyl alcohol is to a greater extent oxidised to a DMBA than are the other two alcohols. Also conjugation with glycine seems to be influenced by sterical factors $(11,36)$. Two enzymes are involved in glycine conjugation, namely acyl CoA synthetase and acyl CoA-glycine $\mathrm{N}$-acyl transferase. The Michaelis constant $\left(\mathrm{K}_{\mathrm{m}}\right)$ for the formation of DMHA from 3,4-DMBA and 3,5DMBA has been estimated to be 420 and $490 \mu \mathrm{M}$, respectively (63). $\mathrm{K}_{\mathrm{m}}$-values of the remaining DMBAs, having methyl groups ortho to the carboxyl moiety, could not be determined in the referred study due to a low yield of the product. The different DMHA-isomers originating from the respective TMB are given in Table 3. The position numbers are valid also for the dimethylbenzyl alcohols and the dimethylbenzoic acids.

All TMBs induce rat liver cytochrome P-450 $(74,87)$. In the lungs, the response is a decreased concentration of pulmonary cytochrome P-450. This finding may be explained by aldehyde intermediates reaching toxic levels due to a deficiency of aldehyde dehydrogenase in the lung. In the liver the aldehydes are rapidly converted to acids (74). One study indicates that 1,3,5-TMB stimulates the glucuronidation route of elimination (89).

\subsection{Toxicity}

\subsubsection{General toxicity}

Acute oral toxicity of $1,2,4-\mathrm{TMB}$ is low based on two independently established $\mathrm{LD}_{50}$ values of 3400 and $6000 \mathrm{mg} / \mathrm{kg}$ (20). Chronic inhalation of a high flash aromatic naphtha containing 45\% TMB (with 1,2,4-TMB being the dominating isomer) at exposure levels up to $165 \mathrm{ppm}$ total TMBs was considered without systemic toxicity on rats (12).

Table 3. Nomenclature of DMHA-isomers

\begin{tabular}{ll}
\hline Parent TMB & DMHA-isomer \\
\hline $1,2,3-\mathrm{TMB}$ & 2,3 -DMHA \\
& 2,6 -DMHA \\
$1,2,4-\mathrm{TMB}$ & $2,4-\mathrm{DMHA}$ \\
& 2,5 -DMHA \\
& $3,4-\mathrm{DMHA}$ \\
$1,3,5-\mathrm{TMB}$ & 3,5 -DMHA \\
\hline
\end{tabular}


Inhalation exposure ( $8 \mathrm{~h} / \mathrm{d}, 14 \mathrm{~d})$ of 1800-2000 ppm 1,2,4-TMB caused no injury (9). Subacute $(6 \mathrm{~h} / \mathrm{d}, 12 \mathrm{~d})$ inhalation of $2000 \mathrm{ppm} 1,2,4-\mathrm{TMB}$ caused respiratory difficulties in rats (28).

The minimal concentration of 1,3,5-TMB vapour causing a loss of reflexes during a 2-h exposure was 7100-9100 ppm. A loss in righting response occurred at inhalation levels of 5100-7100 ppm (56) (the exposure levels reported seem to exceed the approximate saturated vapour concentrations). Single exposure to 560 ppm for $24 \mathrm{~h}$ did not cause any adverse effect in rats whereas animals exposed to 2240 ppm suffered from respiratory failure and depression of the CNS (9). In rats, $6 \mathrm{~h}$ inhalation of 300, 600 and $1200 \mathrm{ppm}$ 1,3,5-TMB caused an increase in neutrophiles at the highest level but no blood count changes (90).

No oral single dose data on 1,2,3-TMB has been found.

In the rat, all TMBs caused disturbed rotarod performance and decreased pain sensitivity performance in a concentration dependent manner after acute 4-h exposures to 250-2000 ppm. Concentration dependent disturbances in the performance of the same tests were seen also at subchronic inhalation of 1,2,3and 1,2,4-TMB at levels up to $250 \mathrm{ppm}$. Decreased pain-sensitivity appeared even at the $25 \mathrm{ppm}$ exposure to 1,2,3-TMB. Generally, the effects after both acute and subchronic exposure of 1,2,3-TMB were more pronounced than those of the other TMBs. In mice, 1,2,4-TMB caused a concentration dependent decrease in respiratory rate and the concentration $(95 \% \mathrm{CI})$ depressing the value to $50 \%$ was 578 (311-793) ppm (47, 48). In male Wistar rats, a 4-week inhalation exposure to 1,2,4-TMB indicated behavioural changes at $100 \mathrm{ppm}$ (increased motor activity, a changed hot plate behaviour and an impaired passive avoidance). Also effects of exposure to $1,2,3-\mathrm{TMB}$ were briefly mentioned in this paper. Passive avoidance was impaired already at $25 \mathrm{ppm}(32)$.

\subsubsection{Irritation}

Liquid 1,3,5-TMB applied for $4 \mathrm{~h}$ to rabbit skin caused severe irritation (42) whereas liquid 1,2,4-TMB had a slight skin and eye irritation potential in a study on rabbits (20). In a briefly reported study, 2000 ppm of 1,2,4-TMB vapour caused eye and nose irritation whereas irritation at $1000 \mathrm{ppm}$ was reported as initial and slight (28). No data on the irritation potential of 1,2,3-TMB was found.

\subsubsection{Reproductive toxicity}

In a 3-generation inhalation reproduction study in rats on C-9 aromatics containing at least $50 \%$ TMBs, fertility was not affected but offspring survival and growth was affected at 272 and $816 \mathrm{ppm}$ total TMBs. No effects on the offspring were seen at the lowest dose level of approximately $55 \mathrm{ppm}$ TMBs. In mice, an aromatic mixture containing $55 \mathrm{ppm}$ TMBs had no developmental effects. At 825 ppm TMBs maternal toxicity was severe and mean fetal weight was largely reduced and developmental defects were seen (20). 


\subsubsection{Genotoxicity and carcinogenicity}

Limited data indicate that the TMBs are not genotoxic (80). No data on carcinogenicity have been found.

\subsubsection{Health effects in humans}

Little information is available on the human toxicity of the TMBs. As occupational exposure generally is to mixtures, the possibility of ascribing potential effects to a single substance is limited.

"Fleet-X-DV-99" is a paint thinner containing $50 \%$ of $1,2,4$ - and $30 \%$ of $1,3,5-$ TMB, and possibly small amounts of the 1,2,3-TMB isomer as well as methylethylbenzene. Workers occupationally exposed to this product at an atmospheric concentration of 10-60 ppm experienced nervousness, tension, anxiety, asthmatic bronchitis, CNS-depression and respiratory irritation. In addition, a tendency towards a deviation from normal coagulation was shown (8). This may, however, be due to the presence of benzene as a contaminant in the solvent mixture (31). One person exposed to 1,2,4-TMB used as a solvent in liquid scintillation counting solutions experienced CNS-symptoms, hepatopathy, chronic gastritis and conjunctivitis (45). Concentration in serum $2 \mathrm{~h}$ after exposure was reported to be $0.20 \mathrm{ppm}$ corresponding to $0.008 \mu \mathrm{M}$.

A recent study on male and female workers occupationally exposed to the solvent mixture Farbasol, consisting of more than $30 \%$ of $1,2,4-\mathrm{TMB}$, and to $95 \%$ of alkyl benzenes, within or below 1.5 of MAK-values (no further information specified), indicated subclinical effects on the CNS. Reported symptoms include headache, vertigo, concentration difficulties, sleep disorders, emotional irritability and mood swings. Some of the symptoms were related to the cumulative dose and/or duration of exposure (40).

\subsection{Occupational exposure and biological monitoring}

High boiling points and relatively high flash points make the TMBs attractive for use in the occupational setting. A major part of occupational exposure to the TMBs, however, originates from exposure to complex mixtures. Exposure occurs in, e.g. the painting, printing and transport industry. TMBs has also occurred in solvent mixtures used for graffiti removal (3). Measurements in the United Kingdom in different industries revealed that virtually all TMB-exposures were below 25 ppm (20).

Several authors have suggested that the DMHAs or DMBAs might be suitable biological markers of exposure to TMBs or TMB-containing products $(6,26,38$, 71). Occupational air levels of the TMBs in the referred studies were below 40 ppm. A positive approximately linear correlation was found between creatininecorrected concentrations of 3,4-DMHA and the time-weighted average (TWA) of 1,2,4-TMB exposure $(26,38)$. 


\subsection{Occupational exposure limits}

The present Swedish occupational exposure limit (OEL) is $25 \mathrm{ppm}$ or $120 \mathrm{mg} / \mathrm{m}^{3}$. The short-time value is $170 \mathrm{mg} / \mathrm{m}^{3}$ (34). A short-time value is a recommended time weighted average value for exposition during a reference period of 15 minutes. The OEL for white spirit is $300 \mathrm{mg} / \mathrm{m}^{3}$ corresponding to approximately $50 \mathrm{ppm}$. Short-time values for white spirit are twice the OELs, $600 \mathrm{mg} / \mathrm{m}^{3}(100$ ppm).

Several countries have an 8-h threshold limit value (TLV)-TWA of $25 \mathrm{ppm}$, including USA (ACGIH) (37), United Kingdom, Australia, Denmark, Finland and Japan (20). In Germany, no MAK-value for the TMBs has been established due to inadequate available data (25). 


\section{Methods}

In this section, a short overview of the methods used is given. More details are given in the original papers. All human exposures were performed after informed consent and according to the Helsinki declaration and were approved by the regional ethical committee at the Karolinska Institute, Solna, Sweden.

\subsection{Determination of liquid/air partition coefficients in vitro (Paper 1)}

By definition, the partition coefficient $(\lambda)$ of a chemical is the ratio of its concentration $(\mathrm{C})$ in two phases at equilibrium.

$$
\lambda \text { liquid/air }=\text { Cliquid } / \mathrm{C}_{\text {air }}
$$

The kinetics of volatile substances depends largely on the partitioning between blood and air and between blood and other tissues. Liquid/air partition coefficients were determined in vitro by the closed vial equilibration method (79). Liquids used were physiological saline, pooled fresh human blood and olive oil. In brief, different amounts of vaporised TMBs were added to pre-sealed vials containing a known volume of the liquid. After equilibration at $37^{\circ} \mathrm{C}$ the head space was analysed by gas chromatography. The same amount of TMBs was added to reference vials containing glass beads instead of liquid. Since no partitioning would occur in the reference vials and all volumes were known, the partition coefficients could easily be calculated.

\subsection{Chamber exposures (Papers II, IV and V)}

Ten male Caucasian volunteers were exposed to vapour of the TMBs in a chamber. The subjects were healthy as judged by a general medical examination including analysis of standard blood chemistry. They were not occupationally exposed to solvents and were instructed to avoid intake of drugs and alcoholic beverages and contact with organic solvents at least 2 days before exposure.

Nominal exposure levels were $25 \mathrm{ppm}\left(120 \mathrm{mg} / \mathrm{m}^{3}\right)$ of each TMB isomer and, in addition, $2 \mathrm{ppm}\left(11 \mathrm{mg} / \mathrm{m}^{3}\right)$ of 1,2,4-TMB. The $25 \mathrm{ppm}$-level corresponds to the present OEL in Sweden. The 2 ppm level was chosen to match exactly the level of 1,2,4-TMB obtained after complete vaporisation of white spirit to reach $300 \mathrm{mg} / \mathrm{m}^{3}$. At a later occasion the same men, except one that could not participate, were exposed nominally to $300 \mathrm{mg} / \mathrm{m}^{3}$ of white spirit (paper V). The exposure to white spirit was conducted approximately one year after the exposure to TMBs. The emphasis was on 1,2,4-TMB as it is the dominating TMB-isomer in white spirit. Exposures were conducted at a physical workload of $50 \mathrm{~W}$ performed on ergometer bicycles to imitate the conditions in light industry work 
(60). The concentration of chamber TMB or white spirit levels were monitored by infrared spectrophotometry. The concentration of TMB in chamber air varied less than $4 \%$ during a $2 \mathrm{~h}$ exposure to $25 \mathrm{ppm}$ and less than $3 \%$ between days, expressed as coefficient of variation. Arterialised blood, urine and exhaled air was sampled during and after exposure and the concentration of parent TMB was analysed by head space (blood, urine) or conventional (exhaled air) gas chromatography.

Arterialisation was achieved by the "heated-hand technique" (68). Heating of the hand was performed by dipping it into hot water before sampling. During exposure, blood was sampled outside the chamber in a transparent glove box flushed with clean air. This procedure was undertaken to minimise the risk of contaminating the samples with solvent outside the chamber. Collected blood was immediately transferred to gas-tight head space vials that were capped with Teflon-coated membranes.

All urine was collected in glass bottles from the onset of exposure and until the following morning. TMB in urine was only determined in samples collected on the day of exposure as they had to be analysed immediately due to the unfavourable partition coefficient. A specimen of each urine sample was stored at $-18^{\circ} \mathrm{C}$ for subsequent analysis of DMHAs by high performance liquid chromatography (HPLC) (Section 3.3). Further, the urinary excretion of unconjugated DMBAs was estimated by analysis of all the urine specimens from one individual, and in addition, by analysis of all urine specimens from all subjects and all exposure conditions but only at $2 \mathrm{~h}$ post exposure.

Exhaled air was sampled at selected intervals in polyester laminated aluminium foil bags. During sampling the subjects wore a nose clip to prevent nasal breathing. Each sampling period was for three minutes. The volume of the expired air was measured with a balanced spirometer. Pulmonary ventilation was measured as the collected air volume (corrected to body temperature and pressure, and saturated air) divided by the sampling time. Ventilation was determined at exercise during exposures and in an upright sitting position post exposure.

Individual blood standards were prepared from blood collected before the subjects went into the chamber. Urine standards were prepared for each individual when voided volumes were adequate. Otherwise the voided volumes for the two subjects that were exposed together were pooled.

All sampling in connection with white spirit exposures was as described above except for exhaled air. Due to a long analysis time of white spirit it was impossible to perform analysis of the expired air in connection with the exposure. Instead, a portion of the samples was transferred to head space vials for subsequent analysis by head space gas chromatography. Standards were prepared by filling polyester laminated aluminium foil bags with a known volume of air and known volumes of liquid white spirit. Standards were treated in exactly the same way as the specimens.

Due to analytical difficulties 1,2,3-TMB in white spirit could only be determined in exhaled air. The 1,3,5-TMB isomer could not be quantitatively 
Table 4. Partial composition of a particular batch of white spirit used in paper V

\begin{tabular}{lclc}
\hline Substance & $\%(\mathrm{v} / \mathrm{v})$ & Substance & $\%(\mathrm{v} / \mathrm{v})$ \\
\hline n-hexane & 0.5 & xylenes & 1.2 \\
n-octane & 0.9 & $1,2,4-\mathrm{TMB}$ & 3.4 \\
n-nonane & 8.1 & $1,3,5-\mathrm{TMB}$ & 2.3 \\
n-decane & 18.9 & $1,2,3-\mathrm{TMB}$ & 1.4 \\
n-undecane & 10.0 & & \\
n-dodecane & 1.4 & & \\
\hline
\end{tabular}

analysed at all due to interfering peaks in the blanks but was detectable in exhaled air and blood.

White spirit, mineral spirit, mineral turpentine, petroleum spirits and Stoddard solvent are all synonyms for a mixture of alkanes, cycloalkanes and aromatic compounds with 7-14 carbon atoms. The relative evaporation rate is 0.15 (butylacetate $=1$ ). Exposure to white spirit is probably a major source of occupational exposure to the TMBs in Sweden. In the present study a traditional white spirit was used, with hydrocarbons predominantly with 7-12 carbon atoms, a boiling point interval of $157-200^{\circ} \mathrm{C}$ and $16 \%$ aromatics (v/v). The flash point was $43^{\circ} \mathrm{C}$. Products of this kind have been shown to contain well over 200 different compounds (19). The proportion of some of the constituents in a particular batch used in the white spirit exposures is given in Table 4, as determined by gas chromatography.

\subsection{Toxicokinetic calculations (Papers II and V)}

Individual kinetic calculations were performed on data from all exposures. The data analysis, however, was somewhat different in Paper II from that in Paper V. In paper II, the post-exposure excretion of unmetabolised solvent in exhaled air was estimated from the area under the respiratory excretion rate versus time curve according to a biexponential expression. Further kinetic calculations were performed by entering blood concentration versus time data into a four compartment mamillary model with zero-order input into the central compartment and first-order elimination by exhalation and metabolism from the central compartment. Thus, other ways of elimination, e.g. renal clearance were considered negligible. Skin uptake was assumed to be zero. Additional input data were net uptake, time of exposure and the amount exhaled post-exposure. The model accounted for the fraction of the absorbed amount cleared by exhalation during and after exposure. For lipophilic substances like the TMBs, use of a multicompartment model is expected as distribution processes are expected to be slow compared with elimination. A four-compartment open model was used as we wanted to depict the washout from lung alveoli, distribution to rapidly and slowly perfused compartments and adipose tissue. In a mamillary model uptake and elimination occur via the central compartment and transfer of chemical takes 


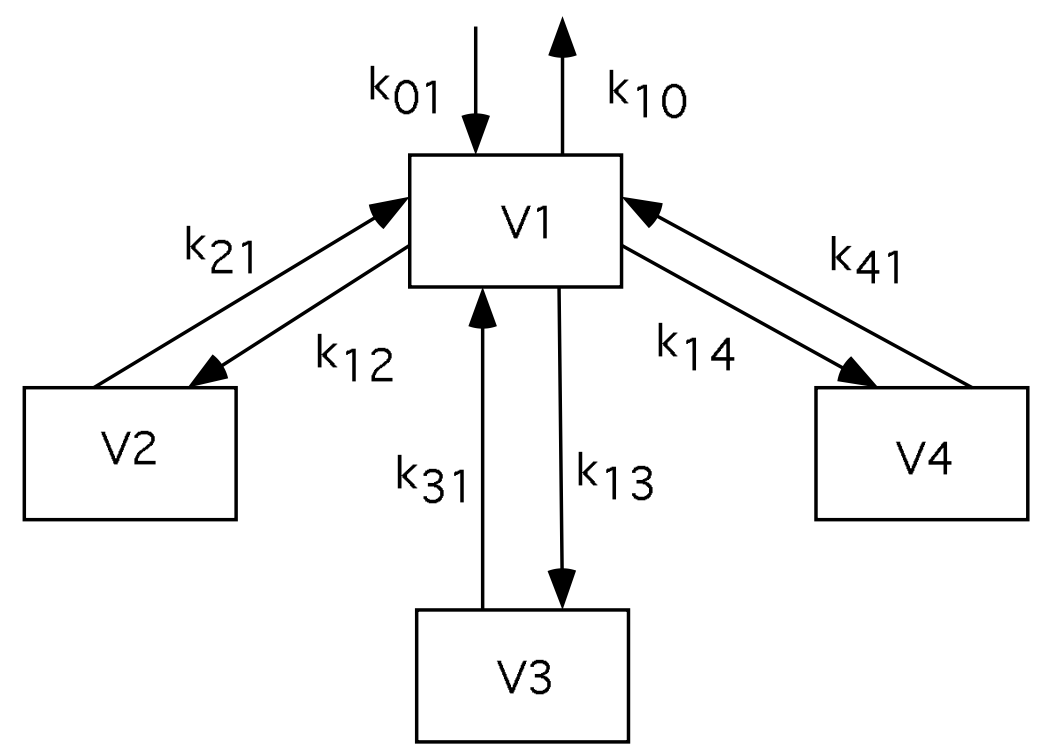

Figure 3. Four compartment mamillary model with uptake and elimination from the central compartment. Dilution volumes $(\mathrm{V})$ and rate constants $(\mathrm{k})$ are depicted.

place between each peripheral compartment and the central one. All processes were assumed to be first-order except for the constant inhalation which was assumed to be zero-order. In fitting the model to the data, the ordinary least squares method (OLS) was used for minimising the residual sum of squares. The model is depicted in Figure 3.

The data from white spirit exposures was put into a two-compartment model. As in the four-compartment model used for TMB-exposures all the processes were first-order except for uptake which was zero-order. The model was simultaneously fitted to the blood and exhalation rate data. The criterion for best fit was the iteratively reweighted least squares (IRLS). The model is depicted in Figure 4.

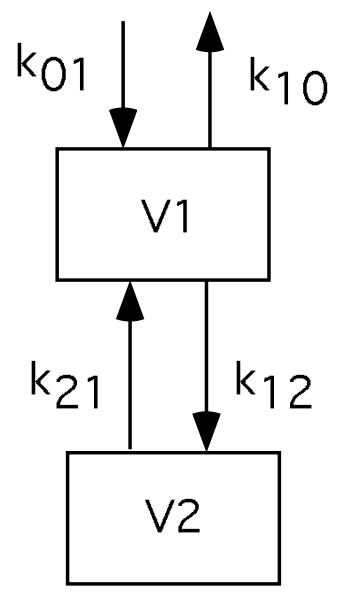

Figure 4. Two compartment model with dilution volumes (V) and rate constants (k). 


\subsection{Chemical analysis of metabolites in urine (Papers III, IV and V)}

A method for the analysis of DMHAs in urine was developed. The method included a clean-up procedure before analysis by HPLC. In brief, $2.5 \mathrm{ml}$ of acidified urine was extracted three times with $5 \mathrm{ml}$ dichloromethane. After evaporation, the residue was dissolved in the mobile phase. Mobile phase A ( $1.25 \%$ acetonitrile and $0.3 \%$ acetic acid in water) was used from the beginning of the chromatographic analysis and up to $59.5 \mathrm{~min}$. Eluent B (5\% acetonitrile and $0.3 \%$ acetic acid in water) was used until termination of the analysis at approximately $90 \mathrm{~min}$. DMHAs were detected at $225 \mathrm{~nm}$. By this method all six DMHAs were separated. Detection limits were less than $1 \mu \mathrm{g} / \mathrm{ml}$ for the main DMHA formed from each TMB isomer, i.e. for 3,4-DMHA (from 1,2,4-TMB), for 2,3-DMHA (1,2,3-TMB), for 3,5-DMHA (1,3,5-TMB) and in addition for 2,4DMHA (1,2,4-TMB).

Unconjugated DMBAs were analysed essentially according to Pfäffli and Savolainen (71) but excluding the hydrolysation step. In addition, $\mathrm{pK}_{\mathrm{a}}$-values for DMHAs and DMBAs were determined by potentiometric titration.

\subsection{Rating of acute symptoms (Papers II and V)}

Irritation and CNS-effects were studied by ratings on a $100 \mathrm{~mm}$ visual analogue scale. The questions included symptoms such as discomfort in eyes, nose, throat or airways, headache, fatigue, nausea, dizziness, intoxication, difficulty in breathing. A question on smell was included to check the sensitivity of the scale to determine feelings of discomfort. The scale was verbally graded from "not at all" to "almost unbearable" (Figure 5).

The scale was originally developed for assessing annoyance from noise in the working environment (46). The questionnaire had previously been used in inhalation studies on mono-terpenes (21).

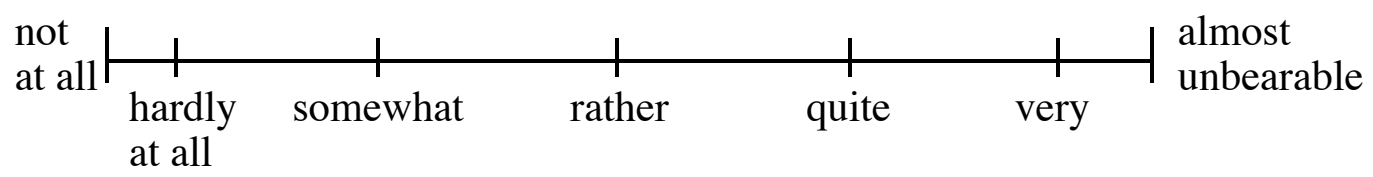

Figure 5. Visual analogue scale for the rating of symptoms in connection with exposure to TMBs and white spirit.

\subsection{Physiologically based modelling of 1,2,4-TMB inhalation kinetics (Paper VI)}

A physiological model describing inhalation kinetics of 1,2,4-TMB was developed. The model was used to investigate how different factors influence potential biological markers of TMB exposure. Experimental data from the 2 and 
25 ppm exposure to 1,2,4-TMB alone was used in the development. It was assumed that all influent chemical is equilibrated within the tissue or compartment, i.e. the transfer rate is limited by blood flow and not diffusion across membranes. Hence, the model is said to be flow- or perfusion-limited.

Tissue/blood partition coefficients were needed for the modelling and were calculated by two approaches. Firstly, empirically derived equations giving tissue/blood partition coefficients from the fat/blood partition coefficient were used (23). Fat/blood partition coefficients for the TMBs were calculated from the previously determined liquid/air partition coefficients (Paper I) assuming that fat tissue consists of $70 \%$ fat and $30 \%$ water. Secondly, tissue/blood partition coefficients for TMB were estimated from tissue composition data (70). The lowest tissue/blood values obtained by the second approach agreed well with those obtained by the empirical relationships. The actual values used in the model was an average of the predictions obtained by the two methods except for the rapidly perfused tissue/blood partition coefficient that could only be estimated by the empirical equation. For convenience, this coefficient was set equal to that obtained for brain (23).

The number of compartments in the model will depend on the chemical specific characteristics and physiological considerations. For inhalation exposure of volatile, lipophilic substances such as the TMBs, a lung and fat compartment is required. The final model was defined by six physiological compartments regarding the transfer of 1,2,4-TMB and, in addition, one compartment describing the formation and excretion of 3,4-DMHA. A special feature of the model was the division of hepatic metabolism into two different routes, one linear (formation of 3,4-DMHA) and one of the Michaelis-Menten type. Further, muscles were divided into two separate compartments of equal volumes corresponding to working and resting muscles. This was done to account for the change in blood flow occurring during exercise (here performed on a bicycle ergometer during exposure) (44). It was assumed that the whole increase in blood flow during exposure was attributed to the compartment of working muscles. Post-exposure work load was set to $25 \mathrm{~W}$ corresponding to normal indoor activities (95). Work load during the night was set to $0 \mathrm{~W}$. Rapidly perfused tissues (brain and kidney) constituted one compartment. The formation of 3,4-DMHA was calculated as the intrinsic clearance for 3,4-DMHA-formation times the 1,2,4-TMB hepatic concentration. The excretion of the metabolite in urine was calculated as an elimination rate constant multiplied by the amount formed.

Individual compartmental volumes and blood flows were scaled according to lean body volume. Blood flows were also adjusted according to work load (17).

The previously obtained experimental data was used to obtain estimates on the following parameters: alveolar ventilation at rest, the metabolic parameters and the rate constant for excretion of 3,4-DMHA. The metabolic parameters were $\mathrm{V}_{\max }$ (maximum metabolic rate) and $\mathrm{K}_{\mathrm{m}}$ (Michaelis-Menten constant) for the route described by Michaelis-Menten-kinetics, and intrinsic clearance for the formation of 3,4-DMHA. Thus, individual simulated blood concentrations, exhalation rates 


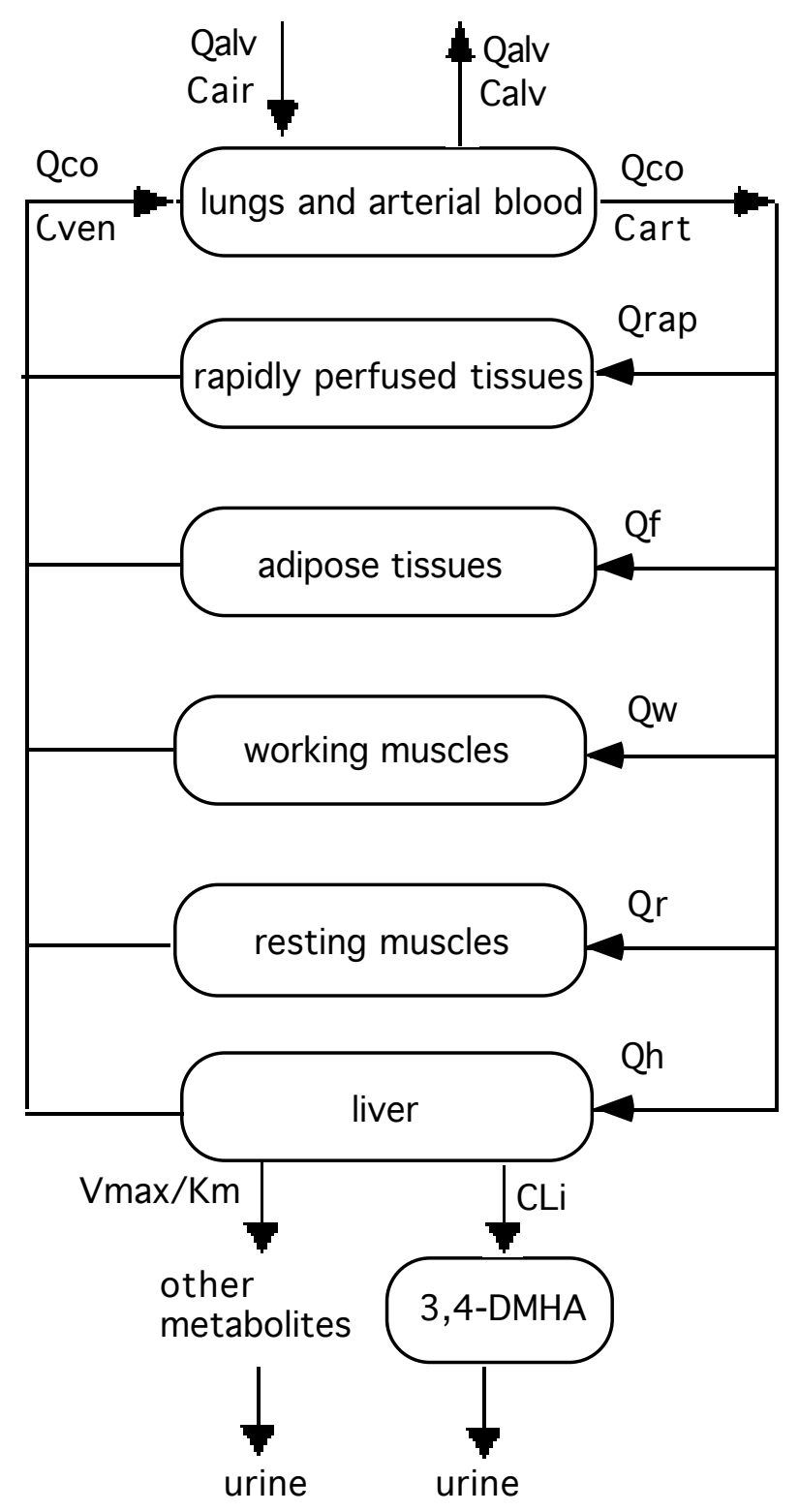

Figure 6. Physiological model for inhaled 1,2,4-TMB.

Qalv = alveolar ventilation; Cair $=$ TMB-concentration in inhaled air; Calv $=$ concentration in alveolar air; Qco = cardiac output; Cart = concentration in arterial blood; Cven = concentration in venous blood $; \mathrm{CLi}=$ intrinsic hepatic clearance; $\mathrm{Qi}=$ blood flow to compartment i; Subscripts for compartment i are as follows; rap = rapidly perfused tissues $; \mathrm{f}=$ adipose tissues; $\mathrm{w}=$ working muscles; $\mathrm{r}=$ resting muscles; $\mathrm{h}=$ liver. 
and urinary excretion rates of 3,4-DMHA were simultaneously fitted to the experimentally determined values from the two exposure conditions by adjusting these five parameters. The IRLS method was used for minimising the residual sum of squares. The parameter values obtained for one of the subjects were used for subsequent simulations of 1,2,4-TMB kinetics at several exposure conditions.

The model was used to expand from the constant $2 \mathrm{~h}$ exposure used in the experiments to constant $8 \mathrm{~h}$ exposure at different work loads and air levels as well as a full working week. The influence from these various conditions on different biological markers of 1,2,4-TMB exposure was investigated. Further, the influence of interindividual variability on biomarker levels was assessed. Moreover, the influence from fluctuating exposure on the level of potential biomarkers was studied by 500 Monte Carlo simulations of randomly generated 8-h exposures with a TWA of $25 \mathrm{ppm}$. Two exposure scenarios were generated. The two scenarios corresponded to a) continuous emissions at a high rate of air exchange and $b$ ) intermittent emissions at a minimal rate of air exchange.

The model was written in the software packages WinNonlin 1.1 (for fitting the model to the data) and Simnon 2.0 (for simulations) and is illustrated in Figure 6.

\subsection{Statistical analysis}

Unless stated otherwise, results are presented as arithmetic means (95\% confidence intervals). Student's paired t-test or repeated measures analysis of variance (ANOVA) was used for comparisons of means regarding kinetic parameters. Subjective ratings were evaluated by repeated measures ANOVA. The level of statistical significance was set to 0.05 . 


\section{Results}

\subsection{Liquid/air partition coefficients (Paper I)}

Blood/air and olive oil/air partition coefficients were high whereas the affinity for water was limited (Table 5). The large values on the blood/air and olive/oil partition coefficients indicate a high respiratory uptake and a high affinity for adipose tissue, respectively. The results are consistent with previous findings with other aromatic hydrocarbons.

From the liquid/air partition coefficients tissue/blood partition coefficients may be calculated. Thus, tissue/blood partition coefficients for the TMBs were predicted by empirical linear correlation equations describing the relation between tissue/blood and adipose tissue/blood partition coefficients. Adipose tissue/blood partition coefficients for the TMBs were calculated based on the fraction of fat $(70 \%)$ and water (30\%) in the tissue (Table 6) (23).

Table 5. Partition coefficients of trimethylbenzenes in blood, water and oil at $37^{\circ} \mathrm{C}$. Mean values and 95\% confidence intervals are given.

\begin{tabular}{llll}
\hline Substance & $\begin{array}{l}\text { Blood/air } \\
\mathrm{n}=39\end{array}$ & $\begin{array}{l}\text { Water/air } \\
\mathrm{n}=42\end{array}$ & $\begin{array}{l}\text { Oil/air } \\
\mathrm{n}=25\end{array}$ \\
\hline $1,2,3-\mathrm{TMB}$ & $66.5(63.7-69.3)$ & $2.73(2.54-2.92)$ & $10900(10500-11300)$ \\
$1,2,4-\mathrm{TMB}$ & $59.1(56.9-61.3)$ & $1.61(1.47-1.75)$ & $10200(9900-10400)$ \\
$1,3,5-\mathrm{TMB}$ & $43.0(40.8-45.2)$ & $1.23(1.11-1.35)$ & $9880(9620-10140)$ \\
\hline
\end{tabular}

${ }^{a}$ strictly physiological saline

\subsection{Inhalation toxicokinetics of the TMBs (Paper II, IV, V)}

During exposure to $25 \mathrm{ppm}$ TMBs for two hours the relative respiratory uptake amounted to 56-64\% for the three isomers (measured net uptake plus the amount cleared by exhalation during exposure). The levels of the TMBs in arterial blood rose rapidly without reaching a plateau during the $2 \mathrm{~h}$ exposure. At the end of exposure, blood levels were on average 6-7 $\mu \mathrm{M}$. The four half-times obtained were 1-2 min, 21-27 min, 4-5 $\mathrm{h}$ and 78-120 $\mathrm{h}$. Thus, the terminal elimination phase of the TMBs is slow. Apparent volumes of distribution were large, 30-39 $1 / \mathrm{kg}$ or 2300-3000 $\mathrm{l}$. These findings are consistent with a substantial accumulation in adipose tissue. Kinetic parameters estimated from the $25 \mathrm{ppm}$ exposures are summarised in Table 7. All results are based on a respiratory uptake calculated as the sum of the measured net uptake and the estimated amount exhaled during exposure. 
Table 6. Calculated tissue/blood partition coefficients derived from (23)

\begin{tabular}{lccc}
\hline Tissue & $1,2,3-\mathrm{TMB}$ & $1,2,4-\mathrm{TMB}$ & $1,3,5-\mathrm{TMB}$ \\
\hline Brain & 4.8 & 5.0 & 6.5 \\
Kidney & 3.1 & 3.2 & 4.0 \\
Liver & 5.5 & 5.8 & 7.5 \\
Lung & 1.6 & 1.6 & 1.8 \\
Muscle & 4.2 & 4.4 & 5.7 \\
\hline
\end{tabular}

Small differences in the kinetics of the TMB isomers were found. The most easily metabolised TMB seems to be the symmetrical 1,3,5-TMB which is logical assuming no special demands on the enzyme-substrate interaction. Average blood levels of 1,2,3-TMB were generally slightly higher and peaked at a level significantly higher than the other TMBs (Figure 7). Further, the respiratory uptake was lower for the 1,2,3-isomer. A slightly slower metabolic elimination of 1,2,3-TMB explains these findings. Assuming metabolism in the liver only, hepatic extraction ratio at the $25 \mathrm{ppm}$-level averaged $0.28 \pm 0.08$ for $1,2,3-\mathrm{TMB}$ indicating that metabolism is to a great extent limited by the enzymatic capacity. Corresponding values were $0.39 \pm 0.07$ for $1,2,4$-TMB and $0.51 \pm 0.08$ for $1,3,5$ TMB indicating that both the enzymatic capacity and hepatic blood flow limit the metabolism.

Table 7. Kinetic results after inhalation exposure to $25 \mathrm{ppm}$ of TMB isomers in 9 $(1,3,5-\mathrm{TMB}$ only) or 10 male volunteers for $2 \mathrm{~h}$ at a work load of $50 \mathrm{~W}$.

\begin{tabular}{llll}
\hline Exposure: & $1,2,3-\mathrm{TMB}$ & $1,2,4-\mathrm{TMB}$ & $1,3,5-\mathrm{TMB}$ \\
\hline Respiratory uptake (\%) & $56 \pm 4$ & $64 \pm 3$ & $62 \pm 3$ \\
Respiratory uptake (mmoles) & $1.4 \pm 0.1$ & $1.6 \pm 0.1$ & $1.6 \pm 0.1$ \\
Respiratory excretion (\%) & $37 \pm 9$ & $20 \pm 3$ & $25 \pm 6$ \\
Urinary excretion $(\% \circ)^{b}$ & $0.023 \pm 0.008$ & $0.010 \pm 0.004$ & $0.016 \pm 0.015$ \\
$\mathrm{CL}_{\text {total }}\left(1 \cdot \mathrm{kg}^{-1} \cdot \mathrm{h}^{-1}\right)$ & $0.63 \pm 0.13$ & $0.68 \pm 0.13$ & $0.97 \pm 0.16$ \\
$\mathrm{CL}$ exhalatory $\left(1 \cdot \mathrm{kg}^{-1} \cdot \mathrm{h}^{-1}\right)$ & $0.23 \pm 0.07$ & $0.14 \pm 0.04$ & $0.24 \pm 0.10$ \\
$\mathrm{CL}_{\text {metabolic }}\left(1 \cdot \mathrm{kg}^{-1} \cdot \mathrm{h}^{-1}\right)$ & $0.39 \pm 0.11$ & $0.54 \pm 0.10$ & $0.72 \pm 0.11$ \\
Half time, 1 st phase $(\mathrm{min})$ & $1.5 \pm 0.9$ & $1.3 \pm 0.8$ & $1.7 \pm 0.8$ \\
$\quad$ 2nd phase (min) & $24 \pm 9$ & $21 \pm 5$ & $27 \pm 5$ \\
\multicolumn{1}{c}{ 3rd phase (h) } & $4.7 \pm 1.6$ & $3.6 \pm 1.1$ & $4.9 \pm 1.4$ \\
4th phase (h) & $78 \pm 22^{c}$ & $87 \pm 27$ & $120 \pm 41^{c}$ \\
Volume of distribution $(1 / \mathrm{kg})$ & $30 \pm 6$ & $38 \pm 11$ & $39 \pm 8$ \\
Mean residence time (h) & $57 \pm 22$ & $69 \pm 32$ & $42 \pm 11$ \\
\hline
\end{tabular}

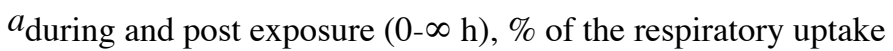

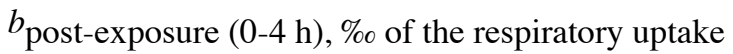
$c_{\mathrm{n}=8}$ 


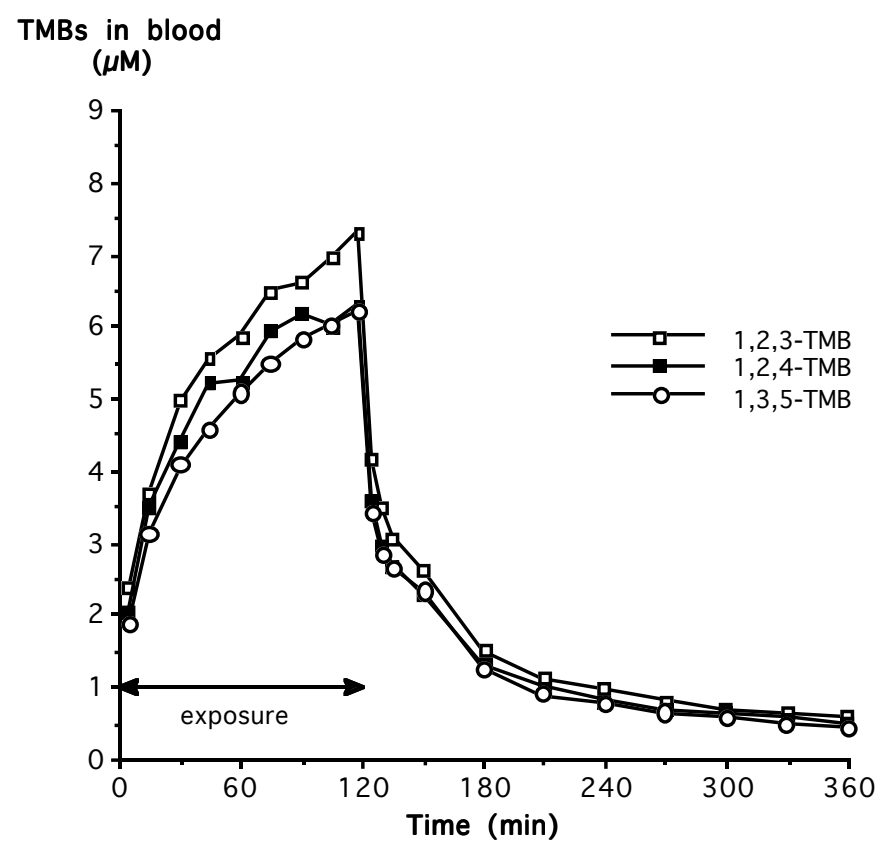

Figure 7. Concentration of TMBs in capillary blood during and after exposure to $25 \mathrm{ppm}$. Mean values of $9(1,3,5-\mathrm{TMB})$ or 10 male volunteers are given.

Individual blood concentrations at steady state $\left(\mathrm{C}_{\mathrm{ss}}\right)$ were calculated as:

$$
\mathrm{C}_{\mathrm{ss}}=\mathrm{R}_{0} / \mathrm{CL}
$$

where $\mathrm{R}_{0}=$ respiratory uptake rate and $\mathrm{CL}=$ total blood clearance.

The $\mathrm{C}_{\mathrm{ss}}$ was significantly lower for $1,3,5-\mathrm{TMB}(11 \pm 2 \mu \mathrm{M})$ than for 1,2,3-TMB $(16 \pm 2 \mu \mathrm{M})$ and for $1,2,4-\mathrm{TMB}(18 \pm 5 \mu \mathrm{M})$.

The interindividual variation in TMB in blood was generally below $20 \%$ during all exposures. However, for the last two blood samples taken in the evening and in the following morning, respectively, the coefficient of variation was elevated (23$51 \%$ ). After the $2 \mathrm{ppm}$ exposure the interindividual variability increased already at approximately $2 \mathrm{~h}$ post exposure.

Experimental and simulated blood concentration versus time curves generally agreed well. Some deviations between predicted and experimental concentrations may be explained by insufficient arterialisation of the blood.

A tendency, although not significant, towards non-linear kinetics was found in the four-compartment analysis of exposure to 2 and 25 ppm 1,2,4-TMB (Paper II). Small differences in respiratory and urinary excretion, mean residence time, clearance and volume of distribution imply a deviation from linearity.

A significant difference in the 1,2,4-TMB kinetics at 2 and $25 \mathrm{ppm}$ was indeed found in the subsequent two-compartment analysis (Paper V). Thus, total clearance was significantly higher at exposure to $2 \mathrm{ppm}$ than at exposure to 25 
ppm 1,2,4-TMB. Exhalatory clearance did not, and should not, differ between exposure conditions. Consequently, the difference in the kinetics between exposure conditions was due to different metabolic clearance values.

Furthermore, the kinetics of 1,2,4-TMB after exposure to 2 ppm 1,2,4-TMB alone and 2 ppm 1,2,4-TMB in white spirit differed in the same way. Blood levels of 1,2,4-TMB as well as urinary excretion rates of 3,4-DMHA were significantly higher after exposure to white spirit as compared with exposure to 1,2,4-TMB alone (Figure 8).

All six possible DMHAs formed from the TMBs were detected in the urine of the exposed men. The studied metabolic pathway was most important for the elimination of 1,2,4-TMB. The 24-h excretion of DMHAs corresponded to approximately $22 \%$ of the inhaled amount of 1,2,4-TMB. About $11 \%$ of the absorbed amount of 1,2,3-TMB was excreted in the urine as DMHAs whereas only $3 \%$ of 1,3,5-TMB was excreted as 3,5-DMHA. Unconjugated DMBAs accounted for in round numbers $3 \%$ of the dose of all TMBs.

The half-times of DMHA excretion rate agreed well between exposure to TMBs only and white spirit (Table 8 ). Half-times ranged from $4-8 \mathrm{~h}$ for all DMHAs except maybe 3,5-DMHA for which some uncertainty about the halftime remains. Half-times for creatinine-corrected concentrations did not differ

\section{$1,2,4-$ TMB in blood $(\mu \mathrm{M})$}

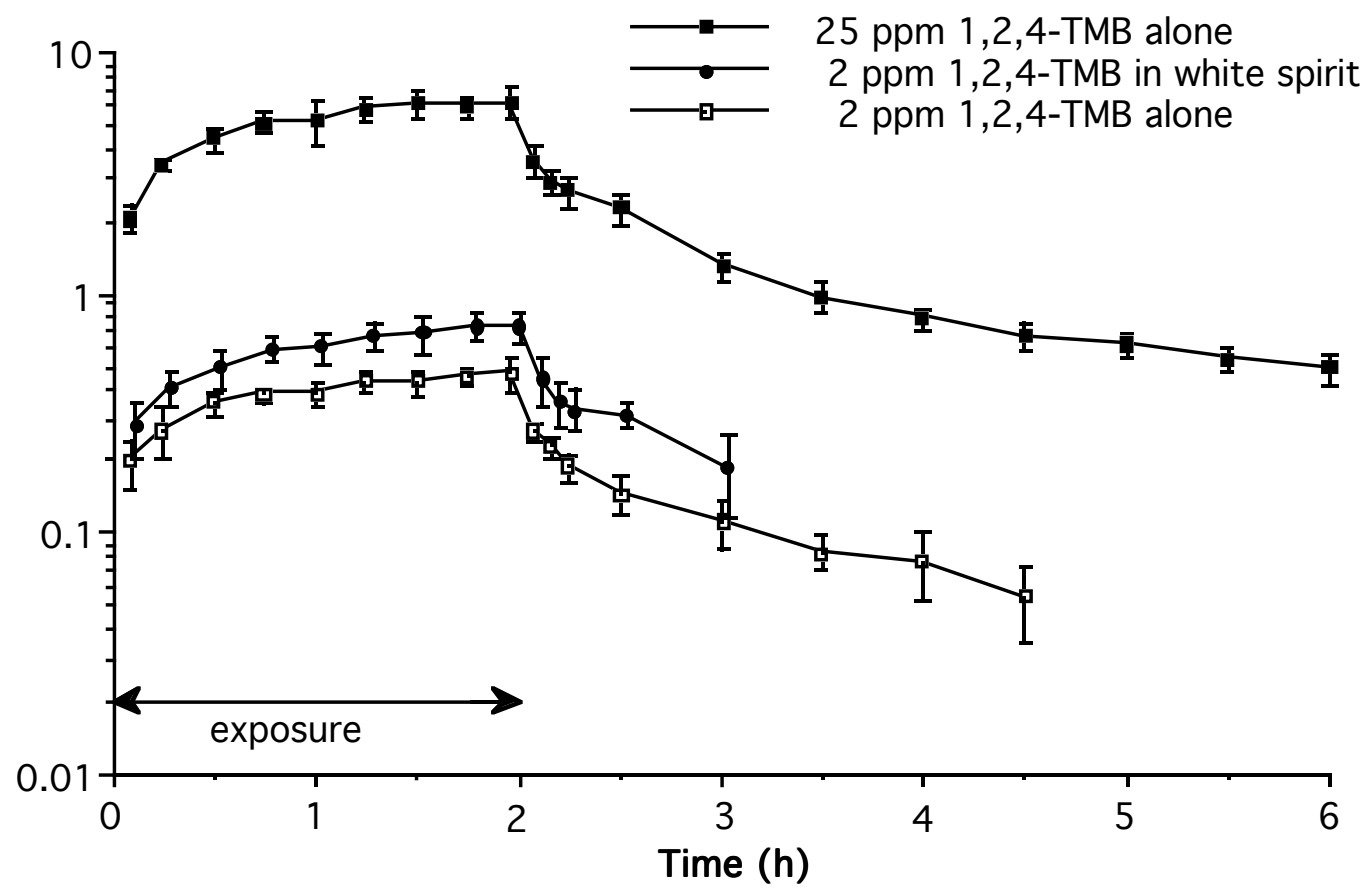

Figure 8. Concentration of 1,2,4-TMB in capillary blood during and after exposure to 2

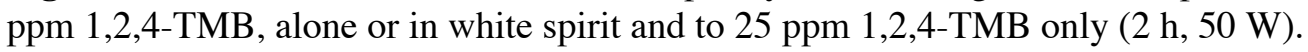
Mean values and $95 \%$ confidence intervals of 9 male volunteers are given. 
Table 8. Half-times of excretion rates of DMHA isomers in urine in volunteers exposed to TMBs alone and in white spirit $(n=9)$. Mean values $(95 \%$ confidence intervals).

\begin{tabular}{|c|c|c|c|c|c|}
\hline $\begin{array}{l}\text { Parent TMB } \\
\text { Metabolite } \\
\text { Exposure }\end{array}$ & 3,4-DMHA & $\begin{array}{l}1,2,4-\mathrm{TMB} \\
2,4-\mathrm{DMHA}\end{array}$ & 2,5-DMHA & $\begin{array}{l}\text { 1,2,3-TMB } \\
2,3 \text {-DMHA }\end{array}$ & $\begin{array}{c}1,3,5 \text {-TMB } \\
3,5 \text {-DMHA }\end{array}$ \\
\hline TMB alone ${ }^{\mathrm{a}}$ & $3.7(3.3-4.1)$ & $5.4(5.0-5.8)$ & $5.7(4.2-7.2)$ & $4.8(3.9-5.7)$ & $15(8-22)$ \\
\hline White spirit & $3.0(2.3-3.7)$ & $5.9(4.4-7.4)$ & $5.8(3.9-7.7)$ & $6.1(4.8-7.4)$ & $7.8(3.9-11.7)$ \\
\hline
\end{tabular}

from those recorded for excretion rate. The variability between subjects however, tended to be larger for half-times of creatinine-corrected concentrations and even more so for the half-times of uncorrected concentrations.

The inter-individual variability in excretion rate of single and combined DMHAs was measured after both single and white spirit exposures. The result from single exposure indicated that the sum of the excretion rate from all six DMHA isomers may reflect the actual exposure more closely than single DMHA isomers. Of individual DMHAs, the 3,4- and the 2,4-DMHA (both originating from 1,2,4-TMB) had the least interindividual variability. Corresponding results from white spirit exposures, however, showed that a summation of DMHA or single 3,4-DMHA had a similar level of interindividual variability (Figure 9).

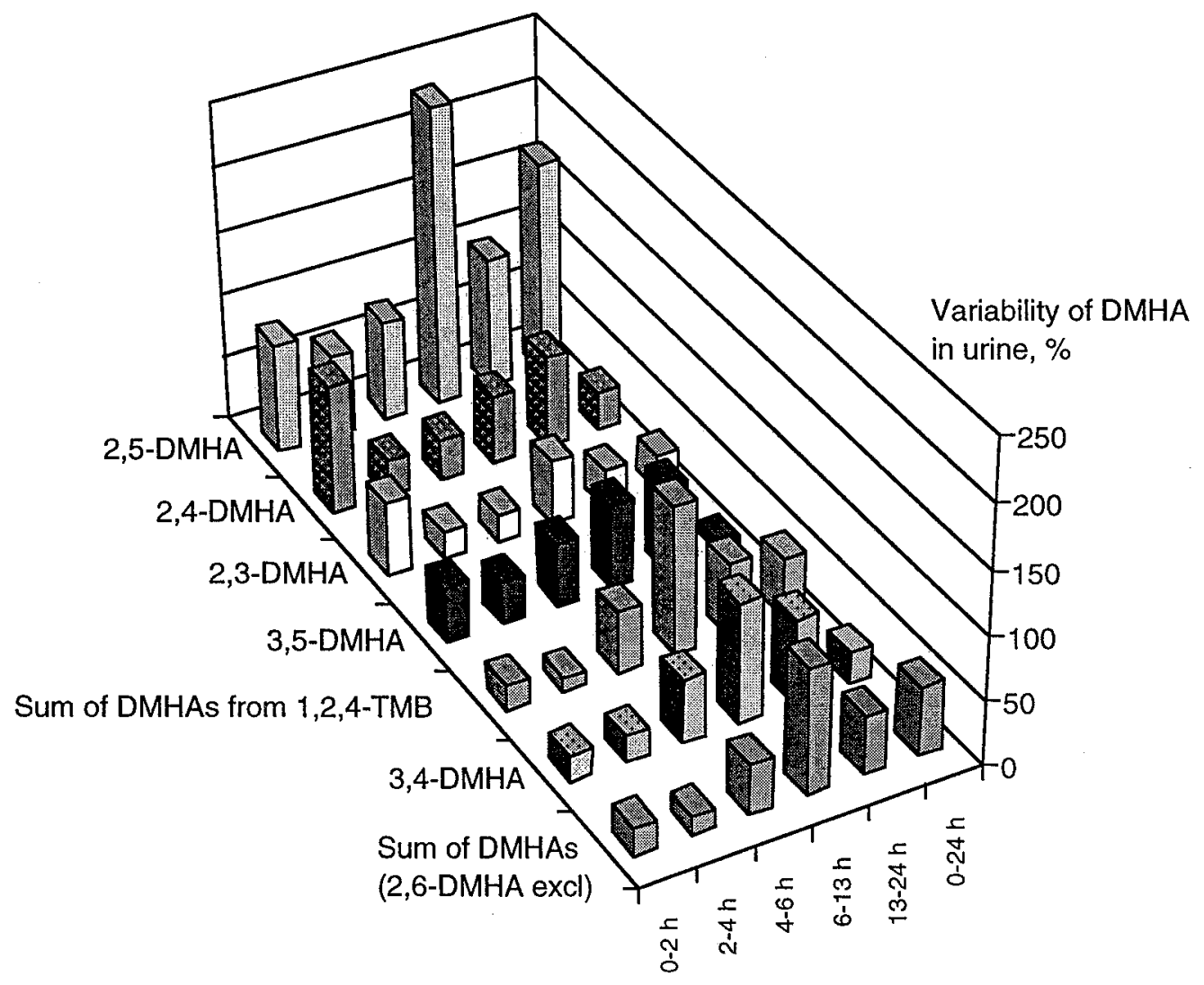

Figure 9. Variability of excretion over time as determined for single and combined DMHA isomers in 9 male volunteers exposed to $300 \mathrm{mg} / \mathrm{m}^{3}$ of white spirit $(2 \mathrm{~h}, 50 \mathrm{~W})$ 


\subsection{Physiologically based modelling of 1,2,4-TMB inhalation kinetics}

Initial simulations with alveolar ventilation at rest set according to literature data filed to mimic the experimental data. However, after individual fitting of the alveolar ventilation and the parameters associated with elimination, the model described the experimental data adequately. However, the final blood concentrations were slightly underpredicted. The metabolic parameters $\mathrm{V}_{\max }$ and $\mathrm{K}_{\mathrm{m}}$ were estimated to $24 \mu \mathrm{mol} / \mathrm{min}$ and $13 \mu \mathrm{M}$, respectively. Values of the same magnitude are reported for toluene and xylene (85).

Simulation of a full working week suggested a slight accumulation in all biomarker levels during the week. This is explained by the high affinity for fat and the large volume and slow perfusion of adipose tissue.

The influence from TMB air levels on biomarker levels is shown in Figure 10. Straight lines are included which indicate the levels expected from first order kinetics. All lines are characterised by an upward bend which illustrates the overall deviation from linear kinetics of $1,2,4-\mathrm{TMB}$. The importance of the metabolic route yielding finally 3,4-DMHA will be enhanced at higher 1,2,4TMB exposure levels since the other metabolic route gradually becomes saturated. Thus, the effect will be more enhanced at the higher concentrations end of shift than prior to shift.

Work load had a profound effect on the level of all biomarker at the end of shift and the following morning (Figure 11). Increasing the work load from rest to moderate exercise $(100 \mathrm{~W})$ resulted in a greater than two-fold increase in all biomarker levels. The effect of work load on the levels of biomarkers depends on

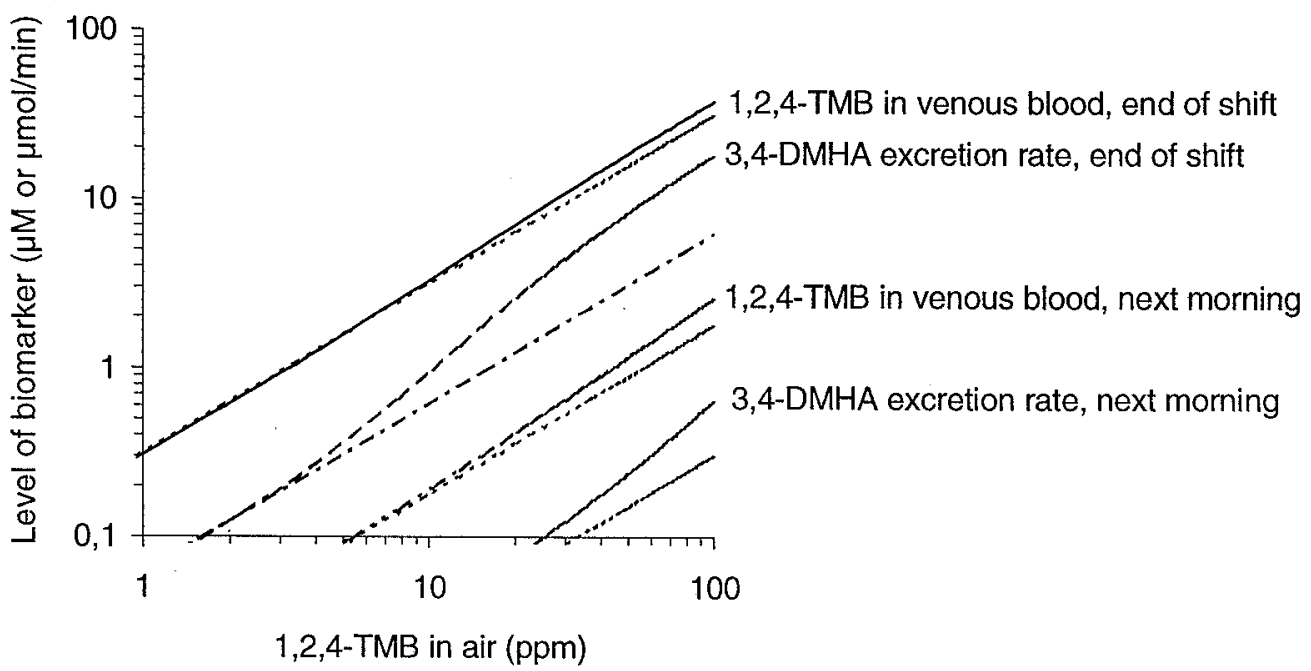

Figure 10. Influence of the 1,2,4-TMB exposure level on biomarker levels at the end of shift and next morning prior to shift. Simulated exposure at a constant level of $25 \mathrm{ppm}$ for $8 \mathrm{~h}(50 \mathrm{~W})$ 

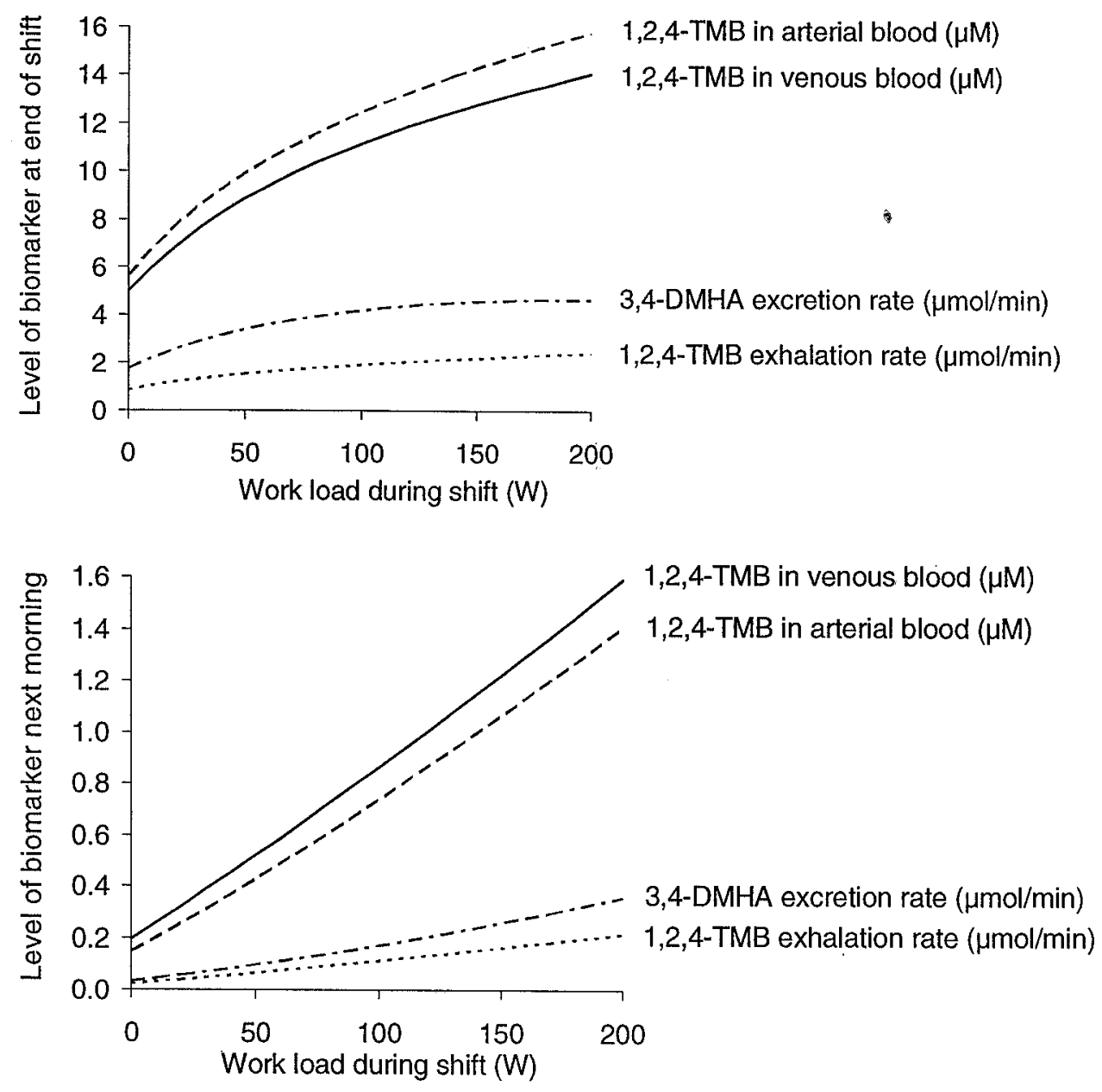

Figure 11. Simulated influence of work load on biomarker levels at a) the end of shift and b) next morning prior to shift after constant exposure to $25 \mathrm{ppm} \mathrm{1,2,4-TMB}$ for $8 \mathrm{~h}$.

the alveolar ventilation, cardiac output, cardiac distribution and the blood/air partition coefficient in a complex manner.

The predicted interindividual variability was approximately $13-15 \%$ for venous blood and 26-29\% for DMHA. Predicted mean values (ranges) for ten subjects after each of five daily 8 -h exposures to $25 \mathrm{ppm} 1,2,4-\mathrm{TMB}$ at the end of shift and next morning prior to shift are given in Table 9.

According to the Monte Carlo simulations the exhalation rate of 1,2,4-TMB is much more influenced by the most recent exposure than are venous blood levels and the excretion of 3,4-DMHA. This is illustrated by a higher variability end of shift after both continuous and intermittent emissions (Table 10). After continuous emissions the variability next morning is approximately equal for all

- biomarkers. After intermittent emissions, the variability of 3,4-DMHA in urine was enhanced compared with that of the other biomarkers. 
Table 9. Predicted biomarker levels for 10 subjects exposed to $25 \mathrm{ppm}$ 1,2,4-TMB at $50 \mathrm{~W} 8 \mathrm{~h}$ daily for five consecutive days.

\begin{tabular}{llll}
\hline & $\begin{array}{l}1,2,4-\mathrm{TMB} \text { in } \\
\text { venous blood }\end{array}$ & $\begin{array}{l}\text { 3,4-DMHA } \\
\text { in urine }\end{array}$ & $\begin{array}{l}\text { 1,2,4-TMB in } \\
\text { exhaled air }\end{array}$ \\
\hline $\begin{array}{l}\text { End of shift } \\
\text { Monday }\end{array}$ & $6.6(5.6-8.4)$ & $2.1(1.5-3.0)$ & $2.8(2.0-4.0)$ \\
Tuesday & $7.0(6.0-9.0)$ & $2.3(1.5-3.3)$ & $2.9(2.1-4.3)$ \\
Wednesday & $7.4(6.3-9.6)$ & $2.4(1.6-3.6)$ & $3.0(2.2-4.5)$ \\
Thursday & $7.7(6.5-10.0)$ & $2.5(1.7-3.8)$ & $3.1(2.3-4.7)$ \\
Friday & $7.96 .7-10.3)$ & $2.6(1.7-4.0)$ & $3.2(2.3-4.8)$ \\
$\quad$ Next morning & & & \\
Tuesday & $0.45(0.36-0.58)$ & $0.090 .06-0.11)$ & $0.06(0.03-0.09)$ \\
Wednesday & $0.73(0.58-0.96)$ & $0.15(0.10-0.19$ & $0.10(0.06-0.16)$ \\
Thursday & $0.96(0.76-1.3)$ & $0.20(0.13-0.27)$ & $0.13(0.08-0.21)$ \\
Friday & $1.1(0.89-1.5)$ & $0.24(0.16-0.35)$ & $0.16(0.09-0.25)$ \\
Saturday & $1.3(0.99-1.8)$ & $0.28(0.18-0.41)$ & $0.18(0.11-0.29)$ \\
Monday & $0.77(0.59-1.01)$ & $0.17(0.11-0.23)$ & $0.12(0.07-0.18)$ \\
\hline
\end{tabular}

\subsection{Acute symptoms}

Ratings of smell during exposure to white spirit and 25 ppm TMB were high, peaking at the first measurement in the chamber at an average of 35-37 $\mathrm{mm}$ for the individual TMBs and at 56 for white spirit. Before leaving the chamber the subjects' average rating of smell had decreased to 20-26. Further, ratings of smell differed significantly between the 2 and $25 \mathrm{ppm}$ levels of 1,2,4-TMB. These results indicate that the rating scale has an ability to pick up feelings of discomfort in a quantitative manner.

No acute symptoms were reported at the studied conditions. Apart from the ratings of smell, all average ratings were below the expression "hardly any effect at all”.

Table 10. Results from Monte Carlo simulations of random fluctuating 8-h exposures to $25 \mathrm{ppm} 1,2,4-\mathrm{TMB}$ at $50 \mathrm{~W}$. Variability (coefficient of variation) in biomarker levels at end of shift and next morning. Scenario 1 corresponds to continuous emission at a high rate of air exchange. Scenario 2 is an intermittent emission at a low rate of air exchange.

\begin{tabular}{lcc}
\hline & End of shift & $\begin{array}{l}\text { Next morning } \\
\text { prior to shift }\end{array}$ \\
\hline Scenario 1 & 1.9 & \\
1,2,4-TMB in venous blood $(\mu \mathrm{M})$ & 13 & 0.8 \\
1,2,4-TMB exhalation rate $(\mu \mathrm{mol} / \mathrm{min})$ & 3.0 & 0.5 \\
3,4-DMHA excretion rate $(\mu \mathrm{mol} / \mathrm{min})$ & 21 & 1.1 \\
Scenario 2 & 64 & 9.7 \\
1,2,4-TMB in venous blood $(\mu \mathrm{M})$ & 36 & 7.5 \\
1,2,4-TMB exhalation rate $(\mu \mathrm{mol} / \mathrm{min})$ & \multicolumn{2}{l}{} \\
3,4-DMHA excretion rate $(\mu \mathrm{mol} / \mathrm{min})$ & &
\end{tabular}




\section{Discussion}

\subsection{Toxicokinetic data analysis}

The traditional toxicokinetic compartmental data analysis has developed rapidly during the last years. However, as computer software is becoming more sophisticated it may need to be stressed that the results depend on the quality of the data as well as factors associated with the data analysis itself. At least some kinetic parameter estimates will depend on the number of compartments in the model used. Parameter estimates may also depend on the mathematical algorithm used to fit the model to the data (69). In the present study, comparisons were made for data analysed by identical software and procedures for fitting model to data. However, when comparing results from different studies this should be kept in mind. For a comprehensive survey of practical pharmacokinetic/-dynamic data analysis the interested reader is referred to, e.g. Gabrielsson et al. (27).

A novel feature of the compartmental analysis in this study was the calculation of the absorbed dose or amount as the sum of measured net uptake and the amount cleared by exhalation during exposure. The traditional approach has been to set dose equal to measured net uptake. As blood levels, and accordingly exhalation rate, increase during exposure, measured net uptake decreases. Thus, by this approach dose related parameters (such as clearance) will depend on the exposure duration. On the other hand, by including clearance by exhalation during exposure it is possible to distinguish between metabolic and exhalatory clearance and the total clearance will be independent of the length of exposure. Lastly, but very important, a more accurate estimation of internal dose is attained.

When analysing data from the single TMB-exposures a four-compartment model was used. After white spirit exposures it was obvious that the shorter follow-up time made the use of that model impossible. To be able to compare the results from all different exposures to 1,2,4-TMB, all data concerning 1,2,4-TMB exposure were re-analysed by a two-compartment model.

The classical databased analysis yields kinetic data for the exposure conditions investigated. Expansions beyond the experimental domain, however, are not possible. On the other hand, physiologically based toxicokinetic (PBTK) models are biologically more realistic and to a great extent based on chemical independent data such as tissue volumes and blood flow data. PBTK-modelling has widened our understanding of the movement of chemicals in the body and of the impact from different factors on tissue concentrations. By physiologically based toxicokinetic modelling we can make predictions about tissue doses and the influence from different exposure scenarios, working conditions and individual characteristics. The increased understanding of the kinetics and its predisposing factors via PBTK-modelling along with the development of sensitive analytical methods has paved the way for biological monitoring and the strategies used for it. 


\subsection{Inhalation toxicokinetics of the TMBs}

\subsubsection{Uptake}

The toxicological profile of a substance may vary with the route of administration. For volatiles occurring in the occupational setting absorption via the respiratory system or the skin is often of greater interest than uptake from the gut wall. Both the lung and the skin exhibit a large surface area exposed to xenobiotics. In the present study, chamber exposure to vapours was performed on subjects wearing a T-shirt and shorts. Theoretically then respiratory and dermal uptake may take place. However, dermal uptake of vapours of highly lipophilic substances like the TMBs is expected to be very limited. Absorption of TMBs in this study has therefore been considered to occur exclusively via the lung. Pulmonary absorption is governed by alveolar ventilation, the blood flow through the lung (cardiac output), the blood/air partition coefficient and elimination.

Experimentally obtained blood /air partition coefficients reflect both solubility and binding. Saturable binding may lead to a deviation from the commonly accepted idea that partition coefficients are constant irrespective of concentration (73). Therefore, the determination of liquid/air partition coefficients in this study was conducted at a wide concentration range covering what is expected to prevail occupationally. No indications of a decreasing blood/air ratio with increasing concentration were found.

For relatively lipophilic substances such as the alkylbenzenes, blood/air and olive oil/air partition coefficients vary approximately according to vapour pressure or boiling point. Thus, from the relatively high boiling points of the TMBs, high blood/air partition coefficients could be expected. This was indeed found and the partitioning to blood was even more pronounced for 1,2,4- and 1,2,3-TMBs than for styrene, an aromatic solvent often referred to as highly blood "soluble".

The blood/air partition coefficient of 1,3,5-TMB was somewhat lower than corresponding values for the other TMBs. The reason for the lower affinity of 1,3,5-TMB for blood is not clear. Interactions between single substances and blood are complex. Hydrophobic solvents seem to be carried in blood mainly by haemoglobin. It may be that the hydrophobic sites of haemoglobin are somewhat rigid and different molecules may not fit equally well in these pockets (54). The determination of the blood/air partition coefficient $(43 \pm 2.2)$ of $1,3,5$-TMB in the present study, however, agrees excellently with the value of 44 previously reported (39). Also, the reported coefficient for 1,2,4-TMB of 54 (86) is close to the result obtained in this study (59). The high blood/air partition coefficients of the TMBs mean that essentially all TMB entering the alveoli will be absorbed by the blood, i.e. absorption is limited by alveolar ventilation.

\subsubsection{Distribution}

Distribution is the transfer of the chemical to and from the site of measurement, which in the present study is whole blood. The process is governed by the partitioning behaviour of the substance. 
The olive/oil partition coefficients found in this study were very high, ranging from 9900 to 10900 indicating extensive distribution to adipose tissue.

Accordingly, water/air partition coefficients were low. However, our result on the water/air partitioning for 1,3,5-TMB (1.2) deviates from the earlier reported urine/air partition coefficient of 18.5 (39). The reason for this discrepancy is not understood. Rat tissue/blood partition coefficients in vivo can be calculated from measured concentrations in different organs after exposure to TMB. The rat fat/blood partition coefficient of 1,2,4-TMB in vivo has been determined to be 63 (92). This value is about half that indicated in the present study. Other data from 12-h inhalation experiments on rats suggests an in vivo fat/blood partition coefficient of about 90 with large variations between groups of animals (18). In the same study the brain/blood partition coefficient was on average 1.7, the liver/blood as well as the kidney/blood partition coefficients were approximately 2. For this kind of data, high affinity tissue/blood concentration ratios tend to be underestimated when measurements of mixed venous blood is performed whereas the opposite holds for a tissue with a low true tissue/blood partition coefficient (30). However, true tissue/blood partitioning coefficients for rats and humans may differ. This is at least partly explained by the fact that many lipophilic compounds have a greater affinity for rat blood than for human blood. For many lowmolecular weight volatiles, blood/air partition coefficients of rats have been found to be 1.5-2.0 times that of humans. For $o$ - and $m$-xylene a ratio of 1.3-1.4 is reported (29).

In a classical compartmental analysis a measure of the extent of distribution is the volume of distribution. Such apparent volume may be visualised as a proportionality factor between total amount in the body and blood concentrations. As this volume was found to be $30-401 / \mathrm{kg}$ for the TMBs, tissue/blood coefficients must be high. However, no human data on tissue/blood partitioning was available but from the liquid/air partition coefficients, tissue/blood coefficients can be predicted which at equilibrium, govern the distribution in the body.

Kinetically, the process of distribution may be limited by perfusion or diffusion across membranes. A small, lipophilic, uncharged molecule such as TMB is assumed to diffuse rapidly across membranes and blood flow may be considered to be rate limiting. Thus, the physiological model used in the present study, was perfusion-limited.

\subsubsection{Elimination}

Elimination is the irreversible loss of the compound from the site of measurement and comprises the processes of biotransformation (metabolism) and excretion. Generally, biotransformation leads to more hydrophilic substances that can be excreted more easily. For substances lacking functional groups, such as TMBs, an initial oxidation step catalysed by the cytochrome P-450 system is required before conjugation to a more water soluble product can occur. It is not known which isoform of the P-450 system is involved in the oxidation of TMBs. However, the ethanol-inducible CYP2E1 has been found to oxidise many relatively small molecules like organic solvents, among them toluene and xylene $(59,67)$. 
Metabolic clearance of the TMBs was moderate and presumably limited by both perfusion and the enzymatic capacity. No steady state was achieved during the course of the 2-h exposures to $25 \mathrm{ppm}$. This is explained by the high blood/air partition coefficient and the moderate metabolic rate.

A moderate metabolic clearance in combination with the large blood flow through the lungs explains the relative importance of exhalation as a route of elimination for the TMBs (20-37\% of respiratory uptake) despite their high blood/air partition coefficients. For the 1,2,3-isomer having the highest blood/air partition coefficient of the TMBs, exhalation is still a more important route of elimination due to a lower rate of biotransformation. For all TMBs, however, experimental measurements of the exhalation rate may be somewhat overestimated due to hyperventilation during sampling. The renal elimination of the unchanged lipophilic TMBs was, as expected, negligible.

Total recovery in this work, taking all elimination routes studied into account, was approximately $30-50 \%$ for the TMBs. Thus, a substantial portion of the absorbed amount has not been accounted for. Considering the diverse spectrum of metabolites possibly formed from the TMBs, this may not be surprising. However, the low recovery of 3,5-DMHA (formed from 1,3,5-TMB) was unexpected considering the results from earlier studies on animals $(53,64)$ and also the human study by Kostrewski and co-workers (49). The difference between our study and the latter may be explained by the fact that we analysed unhydrolysed specimens whereas Kostrewski used hydrolysed urine thereby analysing all possible conjugates of DMBA or even DMHA. The low excretion rate of 3,5-DMHA found in the present study may be explained by a limited water solubility. Indeed, 3,5-DMHA is the least polar of the DMHAs. Furthermore, it is the least acidic (measured as $\mathrm{pK}_{\mathrm{a}}$ ) of the DMHAs and hence, the degree of ionisation in urine is the lowest. Sterical factors are known to influence conjugation with glycine which may explain the lesser importance of this metabolic pathway for 1,2,3-TMB as compared with 1,2,4-TMB.

Also, some sterical influence on the oxidation or glycine conjugation reactions was seen in the relative excreted amounts of different DMHAs from the respective TMBs which is particularly well illustrated by 1,2,4-TMB. The dominating DMHA formed from 1,2,4-TMB was 3,4-DMHA, followed by 2,4DMHA. Excreted amounts of the most sterically hindered 2,5-DMHA were the lowest. Thus, it seems as oxidation/glycine conjugation of positions lacking a neighbouring methyl group is favoured.

Linear kinetics assumes first order transition rates between compartments, i.e. the rate of change of the chemical is proportional to the amount present. Linear kinetics implies also a clearance that is constant and independent of blood concentration. Deviations from linearity may be due to saturable metabolism, cofactor depletion, enzyme induction or inhibition. Inhibition of the metabolism may be due to an effect on $\mathrm{V}_{\max }$ (the maximum rate of the enzyme-substrate reaction) or $\mathrm{K}_{\mathrm{m}}$ (the substrate concentration giving a reaction rate of half $\mathrm{V}_{\max }$ ) or both. Interactions between xenobiotics do occur and have been shown for several 
pairs of substances, see e.g. $(10,84,85)$. Generally, however, interactions have been reported only at higher exposure levels than those used in the present study. Synthetic mixtures of n-nonane, trimethylcyclohexane and 1,2,4-TMB vapour given to rats at levels from 75 to $450 \mathrm{ppm}$ of each substance indicated no interactions between these substances within the experimental domain (18).

In the present study, however, in the initial four compartmental analysis, a tendency (not significant) towards non-linear kinetics of 1,2,4-TMB was found (Paper I). In the subsequent two compartment analysis, however, such a difference appeared (Paper V). One possible explanation to the superior power of the two compartmental analysis as compared with the four compartmental analysis is the fact that the experimental error of the final data points from the 2 ppm exposure to 1,2,4-TMB was too large thereby deteriorating the possibility of detecting any existing difference. By shortening the time of observation included in the analysis, and comprising data points with a higher precision, the difference emerged in the two compartment analysis. Despite indications of non-linear kinetics of 1,2,4-TMB, formation of 3,4-DMHA, seemed relatively unaffected by exposure condition. The urinary excretion rate of 3,4-DMHA was approximately proportional to the area under time blood concentration time curve. Thus, other metabolic pathways must be inhibited and the importance of the studied metabolic pathway is thereby enhanced. As 1,2,4-TMB blood levels were elevated the first step in the biotransformation must be inhibited. Indeed, initial oxidation by the P450 system is generally considered to be the rate limiting step (77). Some sterical influence, although not pronounced, on the initial oxidation of 1,2,4-TMB in the rat seems to occur (36). It may be that the somewhat more rapid oxidation of the carbon in position 4 can proceed at an unaffected rate while the sterically less favoured oxidations of carbon 1 and 2 are inhibited. Comparing the 3rd half-times of the parent TMBs with that of the DMHAs, indicate that the formation (rather than the excretion) of at least 3,4-DMHA $(3.8 \mathrm{~h})$ and 2,3-DMHA $(4.8 \mathrm{~h})$ is rate limiting. The metabolites will then decline with the same half-time as the TMBs (3.8 and $4.7 \mathrm{~h}$, respectively). Regarding 3,5-DMHA, its half-time was not unequivocally determined in this study. In practice, measurements of other metabolites such as dimethylbenzyl alcohols and dimethylbenzoic acids would be necessary to support the speculation of two metabolic pathways of different kinetic orders.

The results from white spirit were unanticipated and must be interpreted with caution. The experimental difficulties regarding the performance of exposures and chemical analysis of complex mixtures are more pronounced than those encountered for single substances.

For instance, the chamber air levels during exposures were monitored with infrared spectrophotometry. This method was chosen to allow for real-time monitoring and control of the chamber air. By this method, absorption in the carbon-hydrogen stretching region was measured. Thus, in the white spirit exposures, the level of several components instead of 1,2,4-TMB alone was monitored. However, the fraction of 1,2,4-TMB was established separately by gas 
chromatography and the chamber air level of 1,2,4-TMB was calculated based on that portion. Furthermore, complete vaporisation was assured when generating standards and chamber vapours. Also, the slight difference between the single exposures to 1,2,4-TMB supports the results from the white spirit exposures. However, the results need to be verified.

\subsection{Physiologically based modelling of 1,2,4-TMB inhalation kinetics}

The main advantage of PBTK modelling compared with traditional data based compartmental analysis is its predictive power. This is due to the fact that PBTKmodels to a large extent depend on chemical independent information but the final model structure will also depend on chemical specific characteristics as well as the aim of modelling. Like all models, PBTK models are simplifications of reality which will help us understand important relationships and the effect of several factors on tissue concentrations and hence, risk. However, one dimension of diversity will be lost. For example, in the modelling process an initial parameterisation is made based on group averages. From a study on interindividual variability in blood/air partition coefficients it was concluded that although significant between-subject variation existed, most subjects could be well represented by group mean values (14). The influence of food intake on blood/air partition coefficients has been studied. Coefficients were larger in samples collected after a meal than in samples collected after fasting (24). Concerning tissue/blood partition coefficients, the variability may be more pronounced. In a study by Pelekis and co-workers extreme values on lipid and water content in different tissues were obtained from the literature (70). A calculation of the corresponding tissue/blood partition coefficients for 1,2,4-TMB indicated wide ranges for liver as well as muscle and adipose tissue/air partitioning. Thus, although many physiological relationships used in PBTKmodelling are well established, the uncertainty regarding some parameters may be considerable.

Factors known to influence the kinetics of volatiles in humans are, e.g. body size and build, sex, physical activity, exposure to other xenobiotics like ethanol and mixed solvents (78). Such factors may be incorporated in the physiological model. In this study the subjects (only males) were asked to refrain from alcoholic beverages and medication prior to exposure. In the TMB-model, organ volumes and blood flows were scaled according to lean body volume, and blood flows also to the physical work load. Post exposure work load was set to $25 \mathrm{~W}$ instead of commonly used $0 \mathrm{~W}$ which improved model fit. The modelled transition between different work loads results in instantaneous changes in affected blood flows. In reality, the process is gradual. Simplifications of this kind in the model may lead to minor deviations between predicted outcome and experimental results.

As a "rule of thumb" the number of compartments should be kept as low as possible to adequately describe the experimental data. The necessity of an additional compartment depends on whether it contributes significantly to the kinetic behaviour or to the toxicity of the chemical. For volatiles like the TMBs, a 
lung compartment is required. In the present model, as for most PBTK-models for inhalation exposure of volatiles, the conducting airways were regarded as inert, i.e. it is assumed that no interaction takes place between the chemical and the surface of the mucous layer in the airways. This is presumably reasonable for chemicals like the TMBs having a low water solubility (43). A special feature of the model was the division of hepatic metabolism in two routes, one of the firstorder and one of the Michaelis-Menten type. The division was based on the results from the chamber exposures indicating an overall slight deviation from 1st order kinetics at $25 \mathrm{ppm}$. Despite the overall non-linear kinetics, the experimental data suggested approximately linear formation of 3,4-DMHA. Another feature of the model was the division of the muscle and skin compartment to account for the effect on blood flow from physical exercise (44). The high TMB affinity for adipose tissue warrant inclusion of a fat compartment.

Metabolism was assumed to occur in the liver only although some biotransformation may occur in other organs such as the lung. Attempts to include pulmonary metabolism in PBTK-models are reported (72). The TMBs have been found to decrease CYP2E1 in the lung (74) which might indicate that pulmonary metabolism of the TMBs occurs. However, as no more quantitative or precise knowledge about that matter was at hand no extra-hepatic metabolism was incorporated in the model.

Data on the liver metabolic constants were needed in the model. However, no such data on 1,2,4-TMB was found. Furthermore, initial simulations revealed that the use of literature data on alveolar ventilation at rest failed to mimic the chamber exposure data. Thus, the experimental chamber exposure data were used to find estimates of $\mathrm{V}_{\max }, \mathrm{K}_{\mathrm{m}}$, intrinsic clearance corresponding to formation of 3,4-DMHA, alveolar ventilation as well as the elimination rate constant of 3,4DMHA. By adjusting these parameters the model could adequately describe the experimental data for all ten subjects. However, the model underpredicted the last two blood concentrations in the evening on the day of exposure and the following morning for most individuals which might indicate the presence of deeper fat depots. Indeed, subcutaneous fat is known to have a lower perfusion than perirenal fat (7). An attempt to divide the fat compartment into two with different blood flows according to Fiserova-Bergerova (22) did not, however, improve the fit. Also, literature data on fat perfusion is uncertain. Thus, in the final model no division of the fat compartment was made.

The great impact from alveolar ventilation on the results for blood and exhaled air was expected as it is a decisive factor for the uptake and exhalation. The estimation of alveolar ventilation at rest $(0 \mathrm{~W})$ obtained from the experimental exposures, approximately $9 \mathrm{l} / \mathrm{min}$ exceeds data in the literature, e.g. Malmberg et al. (61) reports $6.6 \pm 1.8$ (mean $\pm \mathrm{sd}$ ), but our value is still within the normal variation. Alveolar ventilation depends on the lean body volume. Several of the participants in the chamber exposures were physically well trained. They may, therefore, have less adipose tissue and accordingly a larger lean body volume than an average man of the same body size. Thus, alveolar ventilation will be slightly 
increased. Another explanation is that the 1,2,4-TMB exhalation rate is overestimated in the experimental measurements due to hyperventilation.

The effect on blood levels of the physical work load was pronounced. This is expected for substances having a high blood/air partition coefficient (93). During exercise, rate limiting pulmonary ventilation and cardiac output increases which favours the absorption.

The Michaelis-Menten kinetics results in disproportionality between all biomarker levels and 1,2,4-TMB in air. Saturation kinetics will be more pronounced at higher TMB air levels. Thus, the approximate first order formation of 3,4-DMHA means that the importance of 3,4-DMHA formation in the elimination of 1,2,4-TMB will gradually increase with increasing air levels since the other metabolic routes gradually become more saturated.

\subsection{Biological monitoring of TMB exposure}

Biological markers may be defined as molecular, biochemical or cellular changes that are measurable in biological media (35). They represent some event occurring between exposure and disease. Sometimes biomarkers are classified as belonging to either of the following categories: exposure, effect and susceptibility, although the range of markers in fact represents a continuum. In the following the discussion will focus on monitoring of exposure. Our ultimate concern is the target tissue dose (or even the so called biologically effective dose) but surrogate tissue levels such as blood or urine concentrations are often used. A proper selection and use of biomarkers of exposure must be based on the kinetics of the toxicant and its biomarker. Kinetics governs whether peaks or average levels, and what exposure period, will be reflected by the measurement. Further, the timing of sampling has to be based on the kinetic behaviour. Generally, for highly metabolised substances the level of major metabolites correlates better with exposure than the parent molecule (16). Endogenous or background levels of the markers must be considered as well as the interindividual variability. Differences between or within subjects that reflect toxicological differences in internal dose or metabolic capacity should be reflected by the biomarker. Otherwise such differences add to the random background noise. Further, the precision of the analytical assay must be known. The coefficient of variation for a biomarker at different time points will partly reflect a "true" biological variability but is naturally linked to the method used as the analytical error is part of the measured variation. The decision to use a certain chemical as biomarker of exposure must be based on all of these factors together with practical considerations.

In the case of the highly metabolised TMBs, metabolites may be appropriate as biological exposure marker. Other potential biomarkers are TMB-exhalation rate and TMB in venous blood.

Reported urban air levels of the TMBs are in the ppb-ppt-range (55, 81-83) and should not affect the estimates of occupational exposures at the ppm-level. No endogenous formation of DMHAs seems to exist. 
After the $25 \mathrm{ppm}$ experimental exposures to TMBs, the variability between subjects was investigated for DMHA excretion. Half-times of excretion rates, creatinine-corrected and uncorrected concentrations were measured. Excretion expressed as rate showed the least variability. Urine collection, however, may in practice be difficult to achieve. Spot sampling might therefore be a reasonable straightforward alternative. Correction for creatinine improved the precision compared with using uncorrected concentrations. The latter is natural since no correction for dilution is achieved. Creatinine-correction is based on the assumption that the creatinine-excretion is stable over time and not influenced by urine flow rate. This assumption however, has been questioned (2). Adjustment by the specific gravity of the urine specimen is an alternative that does adjust for varying excretion rates of water, but not of any solutes. These two ways of adjusting concentrations are not necessarily interchangeable.

The variability between subjects in DMHA excretion rate was less pronounced for a few hours after exposure. This may indicate that metabolic differences do not have an effect until after some time has past or reflect a somewhat lower analytical precision at lower concentrations. After exposure to single TMBs a summation of the excretion rate of all DMHAs or the excretion rate of 3,4-DMHA had approximately the same variability. After white spirit exposures a summation of DMHAs or 3,4-DMHA had approximately the same variability.

Due to analytical difficulties after white spirit exposure only blood levels of $1,2,4-\mathrm{TMB}$ could be analysed quantitatively. Thus, in the PBTK model it was possible to evaluate 3,4-DMHA as a biological exposure marker but not any markers originating from the other TMBs.

In the PBTK-model, the effect on different biomarkers of a) long term exposure, b) 1,2,4-TMB air levels, and c) work load was simulated.

Simulations of a working week suggested that the biomarker levels a the end of shift remain fairly constant whereas the levels prior to shift increase gradually during the week. It is reasonable to assume that the constant end of shift levels reflect recent exposure (same day) whereas sampling on Friday morning or the following Monday morning will indicate the exposure during the entire working week.

Work load had a pronounced influence on 1,2,4-TMB biomarker levels. Thus, biological monitoring may be advantageous since internal dose during the performance of certain work tasks may be incorrectly estimated by ambient air monitoring.

The importance of the metabolic route yielding 3,4-DMHA increases with increasing air levels. The effect is more pronounced at the end of shift than prior to shift because blood levels at the end-of-shift are high.

As expected, the variability in biomarker levels caused by fluctuating exposures was more pronounced end of shift than next morning. After intermittent emissions with a minimal rate of air exchange the predicted variability in 3,4-DMHA excretion was enhanced compared with the variability of other biomarker levels. This is presumably due the increased importance of 3,4-DMHA formation in the 
elimination of 1,2,4-TMB with increasing air levels. The importance of 3,4-

DMHA formation in the overall elimination of 1,2,4-TMB will then vary with the fluctuating exposure pattern.

The interindividual variation in arterial blood levels end of shift was 13-15\% during the consecutive days, approximately the same as found experimentally. The simulated variation in blood levels is much less than the interindividual variation between single model parameter estimates. This is explained by a covariation between some of the parameters. The subjects in the experimental exposures were all healthy, physically fit, Caucasian males between 26 and 48 years of age. Thus, the variability in this group is presumably smaller than the variability in the general population.

1,2,4-TMB in venous blood or 3,4-DMHA in urine seem suitable as biological markers of TMB exposure. Venous blood levels are slightly less sensitive to air fluctuations. Sampling, however, is invasive and therefore complicated to perform in field studies. On the other hand, urine sampling is non-invasive and the cleanup procedure of the specimen is often easier than that of blood specimens. Analysis of exhaled air is easy but the sampling procedures critical. Further, end of shift levels are highly influenced by the most recent exposure. In general, sampling at the end of shift gives a measure of the exposure during that day whereas sampling prior to shift towards the end of the week or on the following Monday morning will reflect exposure during the whole week.

\subsection{Acute symptoms}

The anaesthetic or narcotic potency of several substances is reported to relate to their olive oil/air or serum/air partition coefficient $(65,66)$. As pointed out by Sato and co-workers (79) the anaesthetic effect of benzene and its methylated derivatives is expected to increase with the number of methyl groups. Accordingly, the TMBs would be more potent in this respect than toluene and xylene.

In the present study ratings of smell during exposure to white spirit and $25 \mathrm{ppm}$ TMB were high, peaking at an average of about 55 and 35-37 mm. Further, ratings of smell differed significantly between the 2 and 25 ppm levels of 1,2,4TMB. These results indicate that the rating scale has an ability to pick up feelings of discomfort quantitatively. The scale itself was validated to noise. The present questions have not been validated against objective measures.

By the questionnaire, no acute symptoms were reported during short-time exposure at the present OELs of trimethylbenzenes and white spirit in Sweden. However, the absence of symptoms does not exclude the possibility of acute effects caused by TMBs. The study was designed for the kinetics and more subjects would have been needed to properly study acute symptoms. Chamber studies, are labour intensive and costly which makes it difficult to study large groups. Also, a selection bias is difficult to avoid in exposure studies since sensitive individuals probably do not volunteer. The small group and the selection 
bias in the recruitment of volunteers means that effects that would be seen in a large, more representative sample of the whole population may not be detected. 


\section{Conclusions}

The toxicokinetics of the TMBs is characterised by:

A high respiratory uptake and a pronounced affinity for adipose tissue and, thus, a potential for accumulation and a slow terminal elimination governed by wash-out from adipose tissue.

Moderate metabolic clearance-values indicating both capacity and flow limited metabolism.

Indications of deviations from first order kinetics were found at an exposure level equal to the present Swedish occupational exposure limit (25 ppm) of 1,2,4-TMB.

Indications of interaction effects from other components in white spirit on the kinetics of 1,2,4-TMB.

A non-linear relationship for 1,2,4-TMB between blood and exposure levels suggesting partial metabolic saturation.

The physiologically based model developed for 1,2,4-TMB implied that:

1,2,4-TMB in venous blood and 3,4-DMHA in urine are suitable as biological markers of 1,2,4-TMB exposure.

The importance of 3,4-DMHA formation in the metabolism of 1,2,4-TMB will increase with increasing TMB air levels. Thus, 3,4-DMHA in urine is non-linearly related to $1,2,4-\mathrm{TMB}$ exposure.

Work load has a profound influence on internal exposure to 1,2,4-TMB and on the excretion of 3,4-DMHA.

Biological sampling end of shift gives a measure of the exposure during the same day whereas sampling prior to shift towards the end of the week reflect exposure during the entire week. 


\section{Summary}

Järnberg, J. Toxicokinetics of inhaled trimethylbenzenes in man. Arbete och Hälsa 1998:1

In the toxicological risk assessment, data on the uptake and disposition (toxicokinetics) of the chemical is important. The three isomeric trimethylbenzenes (TMBs) are widely used as components in solvent mixtures and motor fuels. The aim of the present investigation was to study the human toxicokinetics of inhaled TMB vapours and in particular of 1,2,4-TMB.

Liquid/air partition coefficients of the TMBs were determined in vitro by the vial equilibration method. The results indicate a pronounced affinity for blood and adipose tissue whereas partitioning to water was low. Inhalation chamber exposures of male healthy volunteers were performed for $2 \mathrm{~h}$ during light physical exercise. Exposure level for each TMB-isomer was $25 \mathrm{ppm}$. In addition, an exposure to $2 \mathrm{ppm}$ of $1,2,4-\mathrm{TMB}$ was performed. Furthermore, the same men were exposed to $2 \mathrm{ppm}$ of $1,2,4-\mathrm{TMB}$ in white spirit. A method for determination of dimethylhippuric acids (DMHAs), specific metabolites of TMBs, was developed. The excretion of DMHAs in urine after TMB exposure was measured.

The relative respiratory uptake was high (56-64\%) and exhalation of unmetabolised TMBs amounted to $20-37 \%$ of the absorbed amount. The results from the different exposure conditions indicate a tendency towards a deviation from first order kinetics for 1,2,4-TMB at the present Swedish occupational exposure limit ( $25 \mathrm{ppm})$. This suggests partial metabolic saturation. In addition, 1,2,4-TMB kinetics was affected by other components in white spirit.

The recovery of DMHAs within $24 \mathrm{~h}$ varied between the TMBs isomers in the range $3-22 \%$ of the absorbed amount. Half-times of the DMHAs were in the range 4-8 $\mathrm{h}$. The data suggests that the importance of the metabolic route yielding 3,4DMHA from 1,2,4-TMB increases with increasing air levels and after exposure to white spirit.

A physiologically based toxicokinetic model was developed for 1,2,4-TMB using blood and exhaled air levels of 1,2,4-TMB as well as urinary excretion rates of 3,4-DMHA from the two exposures to 1,2,4-TMB. The model was used to expand from a $2 \mathrm{~h}$ exposure to exposure for $8 \mathrm{~h}$ at different work loads and different air levels as well as exposure during a working week. Simulations indicated that work load has a pronounced influence on 1,2,4-TMB levels in blood and exhaled air as well as the excretion of 3,4-DMHA. Thus, for certain work tasks internal exposure may be incorrectly estimated by air monitoring. $1,2,4-\mathrm{TMB}$ in venous blood or exhaled air and the urinary excretion of 3,4DMHA can be used as biological indicators of 1,2,4-TMB exposure. Sampling at the end of the working shift gives an indication of the same day's exposure whereas sampling prior to shift towards the end of the week or after the weekend reflects the exposure during the entire week.

Key words: trimethylbenzene, dimethylhippuric acid, white spirit, toxicokinetics, biological monitoring, human 


\section{Sammanfattning (Summary in Swedish)}

Järnberg, J. Toxicokinetics of inhaled trimethylbenzenes in man. Arbete och Hälsa 1998:1

Vid toxikologisk riskbedömning av kemiska ämnen är kunskaper om ämnenas upptag och omsättning (toxikokinetik) viktiga. De tre isomererna av trimetylbensener (TMB) förekommer allmänt i lösningsmedelsblandningar och motorbränslen. Syftet med studien var att studera upptag och omsättning av trimetylbensener hos människa.

Fördelningskvoter (vätska/luft) för trimetylbensener bestämdes in vitro i blod, olivolja och vatten. Resultaten tyder på en uttalad affinitet för blod och fettväv. Friska, frivilliga män exponerades i en kammare för ångor av trimetylbensen i $2 \mathrm{~h}$ under lätt fysiskt arbete. Exponeringsnivåerna var 25 ppm av var och en av isomererna och dessutom 2 ppm 1,2,4-TMB. Samma försökspersoner exponerades dessutom för 2 ppm 1,2,4-TMB i lacknafta. En metod utvecklades för bestämning av dimetylhippursyror (DMHA) som är specifika metaboliter av trimetylbensener. Utsöndringen av DMHA i urin mättes efter exponeringarna för trimetylbensener.

Det relativa upptaget av trimetylbensener via andningsvägarna var högt (56$64 \%$ ) och utandning av ometaboliserat lösningsmedel uppgick till $20-37 \%$ av upptagen mängd. Resultaten från de olika exponeringsbetingelserna indikerade en avvikelse från första ordningens kinetik för 1,2,4-TMB redan vid det nuvarande svenska nivågränsvärdet på 25 ppm. Dessutom indikerade lacknaftaexponeringen att kinetiken för 1,2,4-TMB påverkas av övriga komponenter i blandningen.

Utbytet av DMHA inom ett dygn efter påbörjad exponering varierade för de tre isomererna mellan 3 och $22 \%$ av upptagen mängd. Halveringstiderna för DMHA var 4-8 timmar. Resultaten indikerar att betydelsen av den metabolismväg som ger 3,4-DMHA ökar med ökande lufthalter av 1,2,4-TMB.

En fysiologiskt baserad toxikokinetisk modell utvecklades för 1,2,4-TMB med hjälp av data från de två exponeringarna avseende 1,2,4-TMB i blod och utandningsluft samt utsöndringen av 3,4-DMHA. Modellen användes för att expandera från en 2 timmars exponering till heldagsexponering vid olika fysisk arbetsbelastning och exponeringsnivåer. Simuleringarna visade att arbetsbelastningen har stor betydelse för nivåerna av 1,2,4-TMB i blod och utandningsluft. Exponeringen vid tungt fysiskt arbete kan därför underskattas vid mätning av halten 1,2,4-TMB i luft. 1,2,4-TMB i venöst blod eller utandningsluft och 3,4-DMHA i urin kan användas som biologiska markörer för TMBexponering. Provtagning vid slutet av ett arbetspass speglar dagens exponering medan provtagning på morgonen mot slutet av veckan ger ett mått på hela veckans exponering.

Nyckelord: trimetylbensen, dimetylhippursyra, lacknafta, toxikokinetik, biologisk monitorering, människa 


\section{Acknowledgements}

This work was performed at the National Institute for Working Life (formerly the National Institute of Occupational Health). I wish to express my sincere gratitude to all those that have any part in this work and especially:

My first and warmest thanks are to Gunnar Johanson, my tutor and supervisor during these years. I thank you for your enthusiasm, for always rapid, constructive and wholehearted support, and for having faith in me. Very gently, you have guided me through all aspects of research, always willing to share your knowledge. Many thanks also for creating a friendly and open atmosphere in the toxicokinetic group, for letting us all learn how to fly, and for being such a warm and generous person.

Many, many thanks are also due to Agneta Löf, my second tutor in the toxicokinetic group, whom I have bothered frequently for help and pieces of advice. I thank you for being my friend, for always taking your time and for never making me feel that any question was too simple.

Elisabeth Gullstrand and Lena Ernstgård, members of the toxicokinetic group, are acknowledged for excellent and skilful assistance in performing the exposures, for not sparing any effort at times of problems, for being open to new solutions and for contributing to the friendly atmosphere in the group.

All other former and present members of the toxicokinetic group are thanked for the same reason. Annsofi Nihlén also for being my fellow along the stony road towards a PhD-degree, Fredrik Jonsson for help and advice on computational kinetic analysis, and Dorthy Nilsson for helping me maintaining order of worldly things.

Professor Christer Edling, Department of Occupational and Environmental Medicine, University Hospital, Uppsala for giving me an academic home.

Professor Mats Hagberg, my supervisor when this work was initiated, for creating stimulating working conditions during my first years of research.

Bengt Ståhlbom, Department of Occupational Medicine, Laboratory of Occupational Hygiene at the University Hospital of Linköping for a very fruitful and enjoyable co-operation, for always being ready to discuss and exchange ideas about this project and for small talks about life in general. Other members of the laboratory of Occupational Hygiene are also acknowledged, Dan Lindmark, Anette Molbæk and Peter Söderqvist. 
Allan Toomingas is acknowledged for performing the medical examinations and for medical responsibility during the exposures.

The staff at the library of the National Institute for Working Life for rapid and professional help in finding literature about anything.

The subjects on whose blood and urine samples I have spent so much time and effort.

To Ulf, my husband, for continuous and encouraging support and endless discussions about the TMBs, for performing the GC-MS verifications and not least, for patience during these last months.

Finally, to my children Linn and Lovisa for bringing life and joy to me and for not letting me spend too much time on this project.

Financial support was obtained from Swedish OK Environmental Foundation (present name PREEMs Environmental Foundation). 


\section{References}

1. The Merck Index. An Encyclopedia of Chemicals, Drugs, and Biologicals. (12th ed.) White House Station, NJ: Merch \& Co., Inc., 1996:1739. .

2. Alessio L, Berlin A, Dell’Orto A, Toffoletto F, Ghezzi I. Reliability of urinary creatinine as a parameter used to adjust values of urinary biological indicators. Int Arch Occup Environ Health 1985;55:99-106.

3. Anundi H, Lind M-L, Friis L, Itkes N, Langworth S, Edling C. High exposures to organic solvents among graffiti removers. Int Arch Occup Environ Health 1993;65:247-251.

4. Bakke O, Scheline R. Hydroxylation of aromatic hydrocarbons in the rat. Tox Appl Pharmacol 1970;16:691-700.

5. Browning E. Ethel Browning's Toxicity and Metabolism of Industrial Solvents. Amsterdam: Elsevier, 1987; vol 2).

6. Busini S, Bavazzano P. High-performance liquid chromatographic determination of 3,5dimethylhippuric acid in the occupational exposure to trimethylbenzenes. J Chrom 1992;(577):180-184.

7. Bülow J, Trøndevold E. Blood flow in different adipose tissue depots during prolonged exercise in dogs. Pflügers Arch 1982;392:235-238.

8. Bättig K, Grandjean E, Rossi L, Rickenbacher J. Toxikologische untersuchungen über trimethylbenzol. Arch Gewerbepath Gewerbehyg 1958;16:555-566.

9. Cameron GR, Paterson JLH, De Saram GSW, Thomas JC. The toxicity of some methyl derivatives of benzene with special reference to pseudocumene and heavy coal tar naphta. $J$ Path 1938;46:95-107.

10. Campbell L, Wilson K, Samuel M, Gompertz D. Interactions of m-xylene and aspirin metabolism in man. Br J Ind Med 1988;45:127-132.

11. Cerf J, Potvin M, Laham S. Acidic metabolites of pseudocumene in rabbit urine. Arch Toxicol 1980;45:93-100.

12. Clark D, Butterworth S, Martin J, Roderick H, Bird M. Inhalation toxicity of high flash aromatic naphtha. Toxicol Ind Health 1989;5(3):415-428.

13. Cohr K-H, Stokholm J. Exposure of humans to white spirit. II. Methods and analyses. In Danish with English summary. Arbejdstilsynet, Arbejdsmiljøinstituttet, 1979 (3).

14. Dills R, Ackerlund W, Kalman D, Morgan M. Inter-individual variability in blood/air partitioning of volatile organic compounds and correlation with blood chemistry. J Exp Anal Environ Epidem 1994;4(2):229-244.

15. Dowty BJ, Laseter JL. The transplacental migration and accumulation in blood of volatile organic constituents. Pediat Res 1976;10:696-701.

16. Droz P. Biological monitoring I: Sources of variability in human response to chemical exposure. Appl Ind Hygiene 1989;4(1):20-24.

17. Droz PO. Quantification of biological variability. Ann Occup Hyg 1992;36(3):295-306.

18. Eide I, Zahlsen K. Inhalation experiments with mixtures of hydrocarbons. Experimental design, statistics and interpretation of kinetics and possible interactions. Arch Toxicol 1996;70:397-404.

19. Einarsson Ö, Gorczak J, Lundmark B-O, Palmqvist U. Computerized capillary gas chromatographic analysis of hydrocarbon mixtures in workplace air. J Chrom 1990;498:381395.

20. Executive HS. Trimetylbenzenes. Criteria document for an occupational exposure limit. London: HMSO, 1992. 
21. Falk A, Löf A, Hagber M, E W-H, Wang Z. Human exposure to 3-Carene by inhalation: Toxicokinetics, effects on pulmonary function and occurrence of irritative and CNS symptoms. Toxicol Appl Pharmacol 1991;110:198-205.

22. Fiserova-Bergerova $\mathrm{V}$. Inhalation anasthesia using physiologically based pharmacokinetic models. Drub Metab Rev 1992;24(4):531-557.

23. Fiserova-Bergerova V, Diaz ML. Determination and prediction of tissue-gas partition coefficients. Int Arch Occup Environ Health 1986;58:75-87.

24. Fiserova-Bergerova V, Vlach J, Cassady J. Predictable "individual differences" in uptake and excretion of gases and lipid soluble vapours simulation study. Br J Ind Med 1980;37:42-49.

25. Forschungsgemeinschaft D. Occupational toxicants. Critical data evaluation for MAK values and classification of carcinogens volume 4. Commission for the Investigation of Health Hazards of chemical compounds in the Work Area. Weinheim: VHC Verlagsgesellschaft, 1992; vol 4).

26. Fukaya Y, Saito I, Matsumoto T, Takeuchi Y, Tokudome S. Determination of 3,4dimethylhippuric acid as a biological monitoring index for trimethylbenzene exposure in transfer printing workers. Int Arch Occup Environ Health 1994;65:295-297.

27. Gabrielsson J, Weiner D. Pharmacokinetic and pharmacodynamic data analysis. (2nd ed.) Swedish Pharmaceutical society, The Swedish Pharmaceutical Press, 1997:770. .

28. Gage JC. The subacute inhalation toxicity of 109 industrial chemicals. Br J Ind Med 1970;27:1-18.

29. Gargas M, Burgess R, voisard D, Cason G, Andersen M. Partition coefficients of lowmolecular-weight volatile chemicals in various liquids and tissues. Toxicol Appl Pharmacol 1989;98:87-99.

30. Gargas M, Medinsky M, Andersen M. Advances in physiological modeling approaches for understanding the disposition of inhaled vapors. In: Gardner DE, ed. Toxicology of the Lung. 2nd ed.New York: Raven Press, Ltd., 1993: 4561-483.

31. Gerarde HW, Linden NJ. Toxicological studies on hydrocarbons. AMA Archiv Ind Health 1959;19(403):29-44.

32. Gralewicz S, Wiaderna D, Tomas T, Rydzynski K. Behavioural changes following 4-week inhalation exposure to psedocumene (1,2,4-trimethylbenzene) in the rat. Neurotoxicol teratol 1997;19(4):327-333.

33. Hansch C, Leo A. Substituent constants for correlation analysis in chemistry and biology. New York: John Wiley \& Sons, 1979.

34. Health SNBoOSa. Occupational exposure limit values. Ordinance, AFS 1996:2. Swedish National Board of Safety and Health, Solna, Sweden., 1996

35. Hulka BS. Overview of biological markers. In: Hulka BS, Wilcosky TC, Griffith JD, ed. Biological markers in epidemiology. New York: Oxford University Press, 1990: 3-15.

36. Huo J-Z, Aldous S, Campbell K, Davies N. Distribution and metabolism of 1,2,4trimethylbenzene (pseudocumene) in the rat. Xenobiotica 1989;19(2):161-170.

37. Hygienists ACoGI. Threshold limit values for chemical substances and physical agents. Biological exposure indices. Cincinatti, Ohio, 1996

38. Ichiba M, Hama H, Yukitake S, Kubota M, Kawasaki S, Tomokuni K. Urinary excretion of 3,4-dimethylhippuric acid in workers exposed to 1,2,4-trimethylbenzene. Int Arch Occup Environ Health 1992;64:325-327.

39. Imbriano M, Ghittori S, Pezzagno G, Capodaglio E. Urine/air partition coefficients for some industrially important substances. Ital Med Lav 1985;7:133-140.

40. Indulski J, Sinczuk-Walczak H, Szymczak M, Wesolowski W. Neurological and neurophysiological examinations of workers occupationally exposed to organic solvent mixtures used in the paint and varnish production. Int J Occup Med Environ Health 1996;9(3):235-244. 
41. Inspectorate TSNC. Hazard assessments. Chemical substances selected in the Swedish Sunset project. Supplement to KemI report 13/94. 1995 (12/95).

42. Jacobs G, Martens M. Evaluation of the test method for skin irritation as prescribed by OECD and EEC. J Toxicol Cut \& Ocular Toxicol 1987;6(3):215-225.

43. Johanson G. Modelling of respiratory exchange of polar solvents. Ann Occup Hyg 1991;35(3):329-339.

44. Johanson G, Näslund P. Spreadsheet programming - a new approach in physiologically based modelling of solvent toxicokinetics. Toxicol Letters 1988;41:115-127.

45. Kenndler E, Schwer C, Huber JFK. Determination of 1,2,4-trimethylbenzene (Pseudocumene) in serum of a person exposed to liquid scintillation counting solutions by GC/MS. J Anal Toxicol 1989;13:211-213.

46. Kjellberg A, Landström U, Löfstedt P, Wide P, Åkerlund E. Estimation of noise and annoyance in working environments. Arbete och Hälsa 1988;30:1-36.

47. Korsak Z, Rydzynski K. Neurotoxic effects of acute and subchronic inhalation exposure to trimethylbenzene isomers (pseudocumene, mesitylene, hemimellitene) in rats. Int J Occup Med Environ Health 1996;9(4):341-349.

48. Korsak Z, Swiercz R, Rydzynski K. Toxic effects of acute inhalation exposure to 1,2,4trimethylbenzene (pseudocumene) in experimental animals. Int J Occup Med Environ Health $1995 ; 8(4): 331-337$.

49. Kostrewski P, Wiaderna-Brycht A. Kinetics of elimination of mesitylene and 3,5dimethylbenzoic acid after experimental human exposure. Toxicol Lett 1995;77(259-264).

50. Laham S. 1.8 Mesitylene. In: Snyder R, ed. Ethel Browning's Toxicity and Metabolism of Industrial Solvents. Elsevier Science Publisher B.V, 1987: 121-128.

51. Laham S. 1.9 Pseudocumene. In: Snyder R, ed. Ethel Browning's Toxicity and Metabolism of Industrial Solvents. Elsevier Science Publisher B.V, 1987: 129-136.

52. Laham S. 1.10 Hemimellitene. In: Snyder R, ed. Ethel Browning's Toxicity and Metabolism of Industrial Solvents. Elsevier Science Publisher B.V, 1987: 137-142.

53. Laham S, Potvin M. Identification and determination of mesitylenic acidic metabolites in rabbit urine. Toxicol Environ Chem 1988;24:57-69.

54. Lam C-W, Galen T, Boyd J, Person D. Mechanism of transport and distribution of organic solvents in blood. Toxicol Appl Pharm 1990;104:117-129.

55. Lanzerstorfer C, Puxbaum H. Volatile hydrocarbons in and around Vienna, Austria. Water Air Soil Pollut 1990;51:345-355.

56. Lazarew NW. Über die Giftigkeit verschiedener Kohlenwasserstoffdämpfe. Arch Exp Pathol Pharmakol 1929;143:223-233.

57. Leibman K. 2. Enzymatic metabolism of gases and vapors: Problems in relating in vitro experimental results to the situation in vivo. In: Fiserova- Bergerova V, ed. Modeling of inhation exposure to vapors: Uptake, distribution, and elimination. Boca Raton, Florida: CRC Press, Inc., 1983: 29-49. vol I).

58. Lide DR. Handbook of Chemistry and Physics. CRC Press, 1993-1994.

59. Liira J, Elovaara R, Raunio H, Riihimäki V, Engström K. Metabolic interaction and disposition of methylethyl ketone and m-xylene in rats at single and repeated inhalation exposures. Xenobiotica 1991;21:53-65.

60. Löf A, Brohede C, Gullstrand E, et al. The effectiveness of respirators measured during styrene exposure in a plastic boat factory. Int Arch Occup Environ Health 1993;65:29-34.

61. Malmberg P, Hedenström H, Fridriksson HV. Reference values for gas exchange during exercise in healthy nonsmoking and smoking men. Bull Eur Physiopathol Respir 1987;23:131-138.

62. Meylan WM, Howard PH. Atom/fragment contribution method for estimating octanol-water partition coefficients. J Pharm Sci 1994;84(1):83-92. 
63. Mikulski P, Wiglusz R, Galuszko E, Delag G. Reciprocal metabolic effects of benzene and its methyl derivatives in rats. Biul Inst Med Morsk 1979;1:77-88.

64. Mikulski PI, Wiglusz R. The comparative metabolism of mesitylene, pseudocumene and hemimellitene in rats. Toxicol Appl Pharmacol 1975;31:21-31.

65. Miller KW, Paton WDM, Smith EB, Smith BA. Physicochemical approaches to the mode of action of general anesthetics. Anesthesiology 1972;36(4):339-351.

66. Morgan A, Black A, Belcher R. The excretion in breath of some aliphatic halogenated hydrocarbons following administration by inhalation. Ann Occup Hyg 1970;13:219-233.

67. Nakajima T, R.S. W, Elovaara E, et al. Monoclonal antibody directed characterization of cytochrome P-450 isozymes responsible for toluene metabolism in rat liver. Biochem Pharmacol 1991;41:395-404.

68. Nauck MA, Liess H, Siegel EG, Niedmann PD, Creutzfeldt W. Critical evaluation of the "heated-hand-technique" for obtaining "arterialized" venous blood: incomplete arterialization and alterations in glucagon responses. Clin Phys 1992;12:537-552.

69. Pascual B, Montoro JB. Comparative study of four different pharmacokinetic computer programs: case study of factor VIII preparation. Eur J Clin Pharmacol 1997;52:59-64.

70. Pelekis M, Poulin P, Krishnan K. An approach for incorporating tissue composition data into physiologically based pharmacokinetic models. Toxicol Ind Health 1995;11(5):511-522.

71. Pfäffli P, Savolainen H. Urinary dimethylbenzoic acid excretion as an indicator of occupational exposure to white spirit. J Chrom 1985;(337):146-150.

72. Pierce C, Dills R, Morgan M, Nothstein G, Shen D, Kalman D. Interindividual differences in 2H8-toluene toxicokinetics assessed by a semiempirical physiolgically based model. Toxicol Appl Pharmacol 1996;139:49-61.

73. Poulin P, Krishnan K. A mechanistic algorithm for predicting blood:air partition coefficients or organic chemicals with the consideration of reversible binding in hemoglobin. Toxicol ApplPharmacol 1996;136:131-137.

74. Pyykkö K, Paavilainen S, Metsä-Ketälä T, Laustiola K. The increasing and decreasing effects of aromatic hydrocarbon solvents on pulmonary and hepatic cytochrome P-450 in the rat. Pharm Toxicol 1986;60:288-293.

75. Register P. Chemicals Inspectorate, 1998

76. Römer KG, Federsel RJ, Freundt KJ. Rise of inhaled toluene, ethyl benzene, m-xylene, or mesitylene in rat blood after treatment with ethanol. Bull Environ Contam Toxicol 1986;37:874-876.

77. Sato A. The effect of environmental factors on the pharmacokinetic behaviour of organic solvent vapours. Am Occup Hyg 1991;35(5):525-541.

78. Sato A, G. J. Physiological factors affecting the behaviour of orgnic solvent vapors in humans. In: ed. Encyclopedia of Environmental Control Technology. Gulf Publishing Company, Houston, Texas, 1995: 53-85. vol 7. High-Hazard Pollutants).

79. Sato A, Nakajima T. Partition coefficients of some aromatic hydrocarbons and ketones in water, blood and oil. Br J Ind Med 1979;36:231-234.

80. Schreiner CA, Edwards DA, McKee RH, et al. The mutagenic potential of high flash aromatic naphtha. Cell Biol Toxicol 1989;5(2):169-188.

81. Schröder B, Dannecker W. Vehicle emissions as the major source of gaseous aromatic hydrocarbons at different locations in Germay. Sci Total Environ 1994;146/147:275-279.

82. Singh H, Salas L, Cantrell B, Redmond R. Distribution of aromatic hydrocarbons in the ambient air. Atmospheric Environ 1985;Vol 19(11):1911-1919.

83. Singh H, Salas L, Viezee W, Sitton B, Ferek R. Measurement of volatile organic chemicals at selected sites in California. Atmospheric Environ 1992;26A(16):2929-2946. 
84. Tardif R, Charest-Tardif G, Brodeur J, Krishnan K. Physiologically based pharmacokinetic modeling of a ternary mixture of alkyl benzenes in rats and humans. Toxicol Appl Pharmacol 1997;144:120-134.

85. Tardif R, S. L, Krishnan K, Brodeur J. Physiologically based modeling of the toxicokinetic interaction between toluen and m-xylene in the rat. Toxicol Appl Pharmacol 1993;120:266273.

86. Ulfvarson U, Övrum P. Fördelning av lösningsmedel mellan blod och luft för några lättflyktiga lösningsmedel. $A \& H$ 1976;(7).

87. Ungváry G, Szeberényi S, Tátrai E. The effect of benzene and its methyl derivatives on the MFO system. Industrial and Environmental Xenobiotics. Prague, Czechoslovakia: Springer Verlag, Berlin, Heidelberg, New York, 1980: 285-292.

88. van Doorn R, Leijdekkers C-M, Brouns RME, Henderson PT. Alcohol and sulphate intermediates in the metabolism of toluene and xylenes to mercapturic acids. J Appl Toxicol 1981;1(4):236-242.

89. Wiglusz R. The effect of 1,3,5-trimethylbenzene inhalation exposure on the glucuronic acid pathway and activity of some xenobiotic-metabolizing enzymes. Biul Inst Med Morsk 1979;30(2):189-196.

90. Wiglusz R, Kienitz G, Delag G, Galuszko E, Mikulski P. Peripheral blood of mesitylene vapour treated rats. Bull Inst Mar Trop Med (Gdynia) 1975;26:315-322.

91. Zahlsen K, Eide I, Nilsen AM, Nilsen OG. Inhalation kinetics of C6 to C10 aliphatic, aromatic and naphtenic hydrocarbons in rat after repeated exposures. Pharm Toxicol 1992;71:144-149.

92. Zahlsen K, Nilsen AM, Eide I, Nilsen OG. Accumulation and distribution of aliphatic (nnonane), aromatic (1,2,4-trimethylbenzene) and naphtenic (1,2,4-trimethylcyclohexzane) hydrocarbons in the rat after repeated inhalation. Pharm \& Toxicol 1990;67:436-440.

93. Åstrand I. Effect of physical exercise on uptake, distribution and elimination of vapors in man. In: Fiserova- Bergerova V, ed. Modeling of Inhalation Exposure to Vapors: Uptake, distribution and Elimination. Boca Raton, FL: CRC Press Inc., 1983: 107-133. vol 2).

94. Åstrand I, Kilbom Å, Övrum P. Exposure to white spirit. 1. Concentration in alveolar air and blood during rest and exercise. Scand J Work Environ Health 1975;1:15-30.

95. Åstrand P-O, Rodahl K. Textbook of work physiology. (3rd ed.) Singapore: McGraw-Hill Book Company, 1986:756. . 